\title{
3-(吲哚-3-基)-4-(吡唑并[3,4-c]哒嗪-3-基)马来酰亚胺脱氢类 异柠檬酸酶-1 突变体高效抑制剂的合成与评价
}

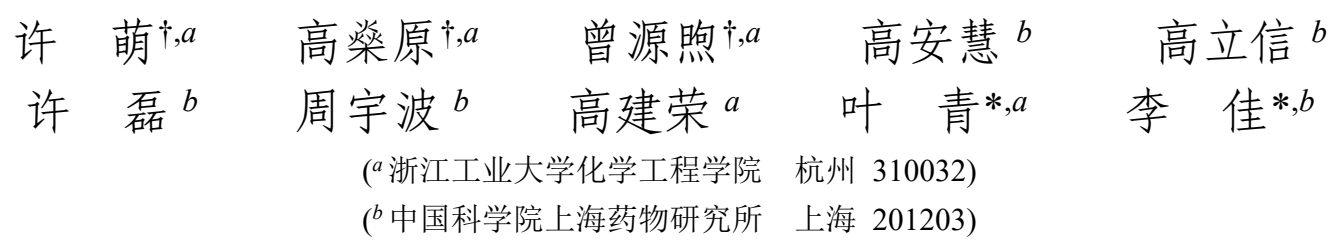

\begin{abstract}
摘要 合成了一系列新型的 3-(吲哚-3-基)-4-(吡唑并 [3,4-c]哒嗪-3-基)马来酰亚胺, 并评价了其对异柠檬酸脱氢酶 1 突变 体 $(\mathrm{R} 132 \mathrm{H})$ 的抑制活性. 大多数化合物对 IDH1-R132H 表现出较强的活性. 其中化合物 3-(1-(3-(1-(1H-咪唑-1-基)丙 基)-6-澳-1 $H$-吲哚-3-基)-4-(1-甲基-1 $H$-吡唑并[3,4-c]达嗪-3-基)-1 $H$-吡咯-2,5-二酮(9b)是最有前途的 IDH1-R132H 抑制剂, $\mathrm{IC}_{50}$ 值为 $31 \mathrm{nmol} / \mathrm{L}$, 并能显著抑制异柠檬酸脱氢酶 1 突变 $(\mathrm{R} 132 \mathrm{H})$ 型人脑星形胶质母细胞瘤细胞中 $2-\mathrm{HG}$ 的产生. 根据 实验数据进行了初步的构效关系讨论和分子模拟研究.

关键词 3-(吲哚-3-基)-4-(吡唑并[3,4-c]哒嗪-3-基)马来酰亚胺; 异柠檬酸脱氢酶 1 突变体(R132H)抑制剂; 合成; 生物 活性
\end{abstract}

\section{Synthesis and Evaluation of 3-(Indol-3-yl)-4-(pyrazolo[3,4- c]pyridazin-3-yl)maleimides as Potent Mutant Isocitrate Dehydrogenase- 1 Inhibitors}

\author{
$\mathrm{Xu}$, Meng ${ }^{\dagger, a} \quad$ Gao, Shenyuan ${ }^{\dagger, a} \quad$ Zeng, Yuanxu $^{\dagger, a} \quad$ Gao, Anhui $^{b} \quad$ Gao, Lixin $^{b}$

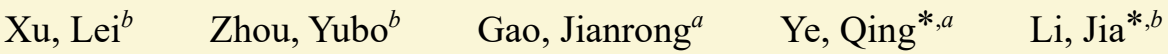 \\ $\left({ }^{a}\right.$ College of Chemical Engineering, Zhejiang University of Technology, Hangzhou 310032) \\ $\left({ }^{b}\right.$ Shanghai Institute of Materia Medica, Chinese Academy of Sciences, Shanghai 201203)
}

\begin{abstract}
A series of novel 3-(indol-3-yl)-4-(pyrazolo[3,4-c]pyridazin-3-yl)maleimides were synthesized and evaluated for their inhibitory activity against mutant isocitrate dehydrogenase-1 (R132H). Most compounds exhibited potent potency to IDH1-R132H. Among them, compound $9 \mathbf{b}$ was the most promising IDH1-R132H inhibitor with IC50 values of $31 \mathrm{nmol} / \mathrm{L}$ and could significantly inhibit the production of 2-HG in human brain astroblastoma cells with mutant isocitrate dehydrogenase-1 (R132H). Preliminary structure-activity relationship and molecular modeling studies were discussed based on the experimental data obtained.

Keywords 3-(indol-3-yl)-4-(pyrazolo[3,4-c]pyridazin-3-yl)maleimide; mutant isocitrate dehydrogenase-1 (R132H) inhibitor; synthesis; biological activity
\end{abstract}

\section{Introduction}

Isocitrate dehydrogenase-1 (IDH1) is a key rate-limiting enzyme in tricarboxylic acid cycle (TCA). Studies have shown that IDH1 has a high mutation rate in several tumors, ${ }^{[1-2]}$ including acute myeloid leukemia (AML), ${ }^{[3-6]}$

\footnotetext{
* Corresponding authors. E-mail: yeqing1975@zjut.edu.cn; jli@simm.ac.cn

Received November 30, 2020; revised January 21, 2021; published online January 28, 2021.

Project supported by the Natural Science Foundation of Zhejiang Province (No. LY18H300009), the Postdoctoral Science Foundation of China (No. 2014M550256), the State Key Laboratory of Drug Research (No. SIMM1601KF-04) and the National Natural Science Foundation of China (No. 8150131067).

浙江省自然科学基金(No. LY18H300009)、中国博士后科学基金(No. 2014M550256)、药物研究国家重点实验室(No. SIMM1601KF-04)及国家自然科 学基金(No. 8150131067)资助项目.

†共同第一作者(These authors contributed equally to this work).
} 
acute lymphoblastic leukemia (ALL), ${ }^{[7-8]}$ myelodysplastic syndrome (MDS),${ }^{[9-10]}$ prostate cancer, ${ }^{[11]}$ glioma, ${ }^{[12]}$ chondrosarcoma ${ }^{[13-14]}$ and cholangiocarcinoma. ${ }^{[15]}$ The mutations of IDH1 mainly include R132H, R132C, R132L, R132S, $\mathrm{R} 132 \mathrm{G}$ and $\mathrm{R} 132 \mathrm{Q}$, among which $\mathrm{R} 132 \mathrm{H}$ is the main mutation and accounts for about $90 \%$ of all cases. After mutation, the functions of IDH1 change in two ways. On one hand, the mutation destroys the affinity of the enzyme, resulting in a decrease in the ability of the enzyme to bind to isocitrate (ICT) $\left(K_{\mathrm{i}}\right.$ and $K_{\mathrm{m}}$ values increase by about 1000 times), and a significant decrease of $\alpha-K G$, which is the decarboxylation product of isocitric acid catalyzed by IDH1. On the other hand, the mutation produces a new catalytic function, which can reduce $\alpha-K G$ to 2-hydroxyglutarate $(2-\mathrm{HG})$, and therefore lead to the accumulation of 2-HG in mutant tumor cells (Scheme 1). Since 2-HG and $\alpha-K G$ share similar structures, they compete with each other in binding to some enzymes. Both of them stated aspects result in a decrease in the activity of some $\alpha-\mathrm{KG}$ dependent dioxygenases, leading to the oncogenesis and development of tumors. ${ }^{[16-17]}$ Therefore, IDH1-R132H has become a potentially attractive anti-tumor target, and screening of appropriate inhibitors has become a hot spot in the development of new anti-tumor drugs.

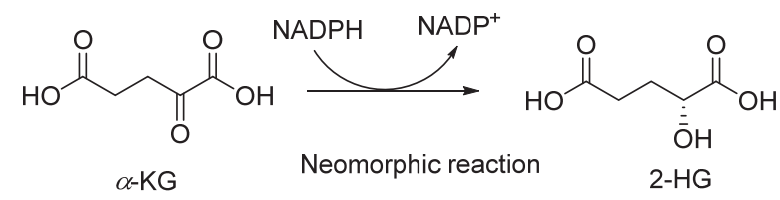

Scheme 1 Reactions catalyzed by mutant isocitrate dehydrogenase-1

In recent years, the development of drugs targeting IDH1 mutants has been widely studied, and inhibitors with several different structure types have been reported. Among them, AG-120, which is developed by Agios Pharmaceuticals and used in the treatment of acute myeloid leukemia (AML), has been approved on July 20th, 2018. ${ }^{[18]}$ In addition, IDH-305 that developed by Novartis Pharmaceuticals and BAY1436032 that developed by Bayer AG have been used for clinical researches. ${ }^{[19-20]}$
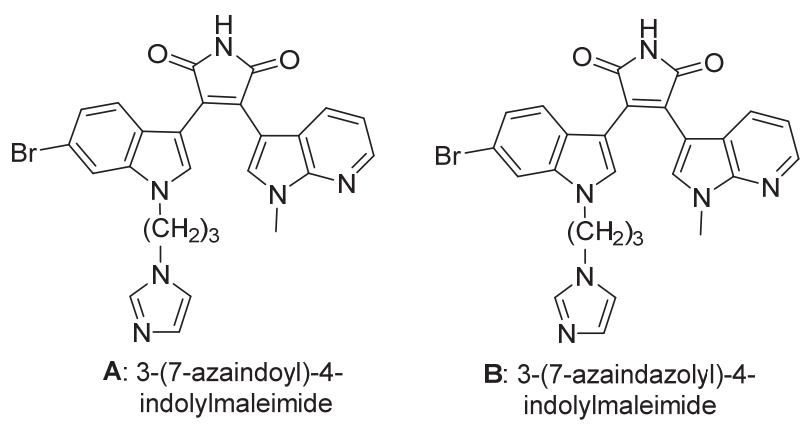

Figure 1 IDH1-R132H inhibitors

In our previous studies we have developed two novel classes of 3-(7-azaindolyl)-4-indolylmaleimide and 3-(7azaindazolyl)-4-indolylmaleimide IDH1-R132H inhibitors (compound $\mathbf{A}, \quad \mathrm{IC}_{50}=280 \pm 14 \mathrm{nmol} / \mathrm{L}$; compound $\mathbf{B}$, $\mathrm{IC}_{50}=61 \pm 5.2 \mathrm{nmol} / \mathrm{L}$ ) (Figure 1). ${ }^{[21-22]}$ Molecular docking studies showed that the substitution of the $\mathrm{C}(6)$ in the 7 -azadiazole ring by a $\mathrm{N}$ resulted in the ability to form a stable hydrogen bond with the amino group of Arg119 using the $\mathrm{N}$ atom as a hydrogen bond acceptor, which may improve the inhibitory activity of the compound. For the reasons stated above, in this study, a pyrazolido[3,4-c]pyridazine ring was used to replace the 7 -azadiazole ring of 3-(7-azaindazolyl)-4-indolylmaleimides. The substituents on the indole ring and the $\mathrm{N}$ atoms in maleimide, indole, and 7-azaindazole rings were also modified to study the structure-activity relationship. Thus, a series of 3-(indol-3-yl)-4(pyrazolo[3,4-c]pyridazin-3-yl)maleimide small-molecule inhibitors of IDH1-R132H were designed and synthesized and the biological activity was studied. The protein binding patterns of these compounds were also studied.

\section{Results and discussion}

\subsection{Chemistry}

The synthetic route of compounds $9 \mathbf{a} \sim 9 \mathbf{i}$ is illustrated in Scheme 2. Diazotizing $\mathbf{1}$ with hydrochloric acid and $\mathrm{NaNO}_{2}$, then reacted with $\mathrm{KI}$ to afford 2. 2 was treated with $\mathrm{EtMgBr}$, then reacted with $\mathrm{Sn}(\mathrm{Bu})_{3} \mathrm{Cl}$ in dry THF to result in 3. ${ }^{[23]}$ Alkylation of $\mathbf{3}$ with methyl iodide, bromoethane or 1-bromobutane in the presence of $\mathrm{NaH}$ in dry DMF afforded $\mathbf{4 a} \sim \mathbf{4} \mathbf{c}$ respectively. 5a $\sim \mathbf{5 e}$ were treated with $\mathrm{EtMgBr}$, then reacted with 3,4-dichloro-1-phenyl-1Hpyrrole-2,5-dione in dry THF to result in $\mathbf{6 a} \sim \mathbf{6 e}$. Stille coupling of $\mathbf{4 a} \sim \mathbf{4} \mathbf{c}$ with $\mathbf{6 a} \sim \mathbf{6 e}$ using $\mathrm{Pd}\left(\mathrm{Ph}_{3}\right)_{2} \mathrm{Cl}_{2}$ as a catalyst in dry toluene afforded intermediate $\mathbf{7 a} \sim \mathbf{7 g} .{ }^{[24]}$ Alkylation of $\mathbf{7 a} \sim \mathbf{7 g}$ with 1-(3-chloropropyl)-1H-imidazole in the presence of $\mathrm{NaH}$ in dry DMF yielded $\mathbf{8 a} \sim \mathbf{8 g}$. Target compounds $\mathbf{9 a} \sim \mathbf{9 g}$ were synthesized by treating $\mathbf{8 a} \sim \mathbf{8 g}$ with melted $\mathrm{NH}_{4} \mathrm{OAc}$. Treatment of $\mathbf{7 b}$ with melted $\mathrm{NH}_{4} \mathrm{OAc}$ afforded $\mathbf{9 h}$. Reaction of $\mathbf{8 b}$ with methylamine in alcohol afforded compound $\mathbf{9 i}$.

To efficiently synthesize the target compounds, a preliminary study of the stille coupling reaction was conducted. Compounds $\mathbf{4 a}$ and $\mathbf{6 a}$ were used as model substrates to investigate the reaction conditions, including factors such as palladium catalyst, additive, solvent type and reaction temperature (Table 1). Product 7a was initially obtained with a yield of $76.9 \%$ via the reaction between $4 \mathbf{a}(0.57$ $\mathrm{mmol})$ and $6 \mathbf{6}(0.62 \mathrm{mmol})$ with $\mathrm{Pd}\left(\mathrm{PPh}_{3}\right)_{2} \mathrm{Cl}_{2}(15 \mathrm{~mol} \%)$ as the catalyst, $\mathrm{LiCl}(1.30 \mathrm{mmol})$ as the additive, and anhydrous PhMe $(25 \mathrm{~mL})$ as the solvent, performed at $100{ }^{\circ} \mathrm{C}$ for $2 \mathrm{~h}$ under a nitrogen atmosphere. Further studies showed that replacing the catalyst with $\mathrm{Pd}\left(\mathrm{PPh}_{3}\right)_{4}$ or $\mathrm{PdCl}_{2}(\mathrm{dppf})$, or replacing the additive $\mathrm{LiCl}$ with $\mathrm{CsF}$ caused a decrease in the yield. When 1,4-dioxane was used as the solvent, the yield was significantly increased (94.5\%) and reducing the amount of catalyst or lowering the temperature led to a significant decrease in yield. Therefore, the optimal conditions were a reaction temperature of $100{ }^{\circ} \mathrm{C}$ with $1,4-\mathrm{di}-$ oxane as the solvent, $\mathrm{Pd}\left(\mathrm{PPh}_{3}\right)_{2} \mathrm{Cl}_{2}$ as the catalyst, and $\mathrm{LiCl}$ 


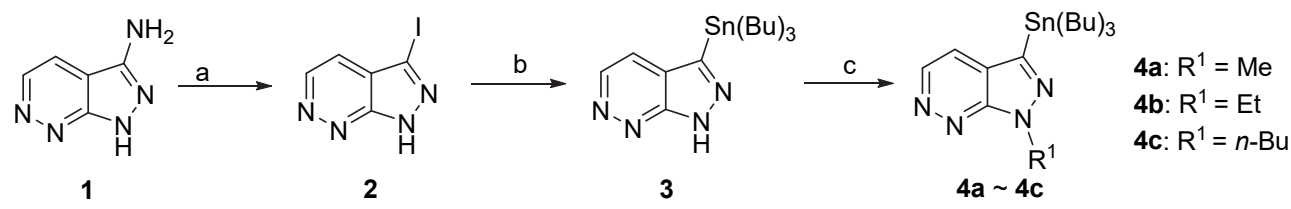<smiles>[R]c1ccc2cc[nH]c2c1</smiles>

5a, 6a: $R^{2}=H ; 5 d, 6 d: R^{2}=5-F ; 5 b, 6 b: R^{2}=6-B r \quad 7 a \sim 7 g$

5e, 6e: $R^{2}=6-M e ; 5 c, 6 c: R^{2}=6-F$
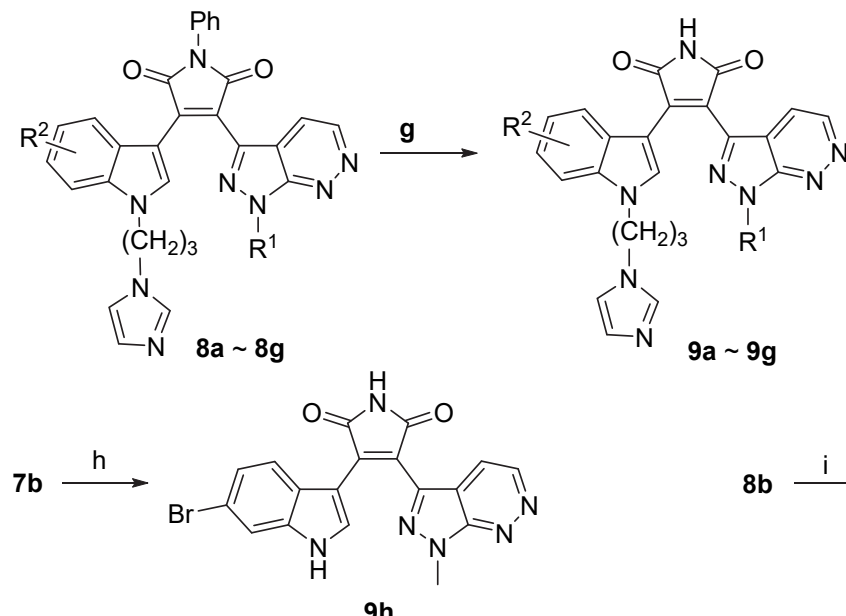

7a, 8a, 9a $\mathrm{R}^{1}=\mathrm{Me}, \mathrm{R}^{2}=\mathrm{H}$

$7 b, 8 b, 9 b R^{1}=M e, R^{2}=6-B r$

$7 c, 8 c, 9 c \quad R^{1}=M e, R^{2}=6-F$

7d, 8d, 9d $R^{1}=M e, R^{2}=5-F$

$7 e, 8 e, 9 e R^{1}=M e, R^{2}=6-M e$

7f, 8f, 9f $R^{1}=E t, R^{2}=6-B r$

$7 \mathrm{~g}, \mathbf{8 g}, 9 \mathrm{~g} \mathrm{R}^{1}=n-\mathrm{Bu}, \mathrm{R}^{2}=6-\mathrm{Br}$

$9 \mathrm{~h}$

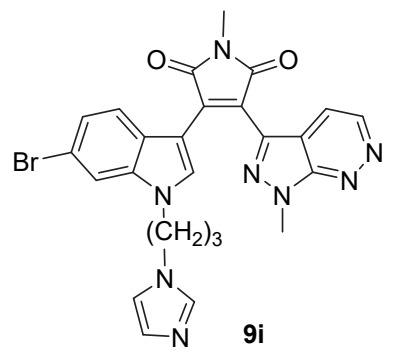

Reagents and conditions: (a) $\mathrm{HCl}, \mathrm{NaNO}_{2}, \mathrm{Kl}$; (b) EtMgBr, $\mathrm{Sn}(\mathrm{Bu})_{3} \mathrm{Cl}$, THF; (c) NaH, R${ }^{1}$; (d) EtMgBr, 3,4-dichloro-1-phenyl-1H-pyrrole2,5-dione, THF; (e) $\mathrm{Pd}\left(\mathrm{Ph}_{3}\right)_{2} \mathrm{Cl}_{2}$, LiCl, toluene; (f) 1-(3-chloropropyl)-1H-imidazole, $\mathrm{NaH}$, DMF; (g) $\mathrm{NH}_{4} \mathrm{OAc}$; (h) $\mathrm{NH}_{4} \mathrm{OAc}$; (i) $\mathrm{CH}_{3} \mathrm{NH}_{2}$

Scheme 2 Synthetic route of compounds $9 \mathrm{a} \sim 9 \mathrm{i}$

Table 1 Optimization of the stille couping reaction conditions ${ }^{a}$

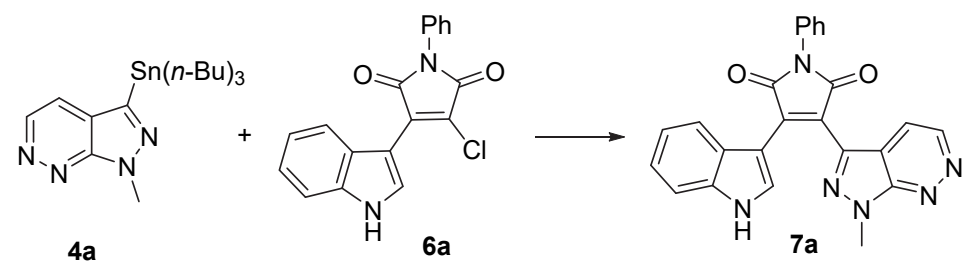

\begin{tabular}{|c|c|c|c|c|c|c|}
\hline Entry & Pd-cat & Solvent & Temp. $/{ }^{\circ} \mathrm{C}$ & $\mathrm{Pd}$-cat $/ \mathrm{mol} \%$ & Additive & Yield $^{b} / \%$ \\
\hline $1^{c}$ & $\mathrm{Pd}\left(\mathrm{PPh}_{3}\right)_{2} \mathrm{Cl}_{2}$ & $\mathrm{PhMe}$ & 100 & 15 & $\mathrm{LiCl}$ & 76.9 \\
\hline 2 & $\mathrm{Pd}\left(\mathrm{PPh}_{3}\right)_{4}$ & $\mathrm{PhMe}$ & 100 & 15 & $\mathrm{LiCl}$ & 69.9 \\
\hline 3 & $\mathrm{PdCl}_{2}(\mathrm{dppf})$ & $\mathrm{PhMe}$ & 100 & 15 & $\mathrm{LiCl}$ & 56.2 \\
\hline 4 & $\mathrm{Pd}\left(\mathrm{PPh}_{3}\right)_{2} \mathrm{Cl}_{2}$ & $\mathrm{PhMe}$ & 100 & 15 & $\mathrm{CsF}$ & 68.3 \\
\hline 5 & $\mathrm{Pd}\left(\mathrm{PPh}_{3}\right)_{2} \mathrm{Cl}_{2}$ & $\mathrm{PhMe}$ & 100 & 15 & - & 39.3 \\
\hline 6 & $\mathrm{Pd}\left(\mathrm{PPh}_{3}\right)_{2} \mathrm{Cl}_{2}$ & DMF & 100 & 15 & $\mathrm{LiCl}$ & 22.9 \\
\hline 7 & $\mathrm{Pd}\left(\mathrm{PPh}_{3}\right)_{2} \mathrm{Cl}_{2}$ & 1,4-Dioxane & 100 & 15 & $\mathrm{LiCl}$ & 94.5 \\
\hline 8 & $\mathrm{Pd}\left(\mathrm{PPh}_{3}\right)_{2} \mathrm{Cl}_{2}$ & $\mathrm{CH}_{3} \mathrm{CN}$ & 100 & 15 & $\mathrm{LiCl}$ & Trace \\
\hline 9 & $\mathrm{Pd}\left(\mathrm{PPh}_{3}\right)_{2} \mathrm{Cl}_{2}$ & 1,4-Dioxane & 100 & 10 & $\mathrm{LiCl}$ & 77.6 \\
\hline 10 & $\mathrm{Pd}\left(\mathrm{PPh}_{3}\right)_{2} \mathrm{Cl}_{2}$ & 1,4-Dioxane & 100 & 5 & $\mathrm{LiCl}$ & 61.5 \\
\hline 11 & $\mathrm{Pd}\left(\mathrm{PPh}_{3}\right)_{2} \mathrm{Cl}_{2}$ & 1,4-Dioxane & 90 & 15 & $\mathrm{LiCl}$ & 63.7 \\
\hline
\end{tabular}

${ }^{a}$ Reaction conditions: 4a $(0.57 \mathrm{mmol}), 6 a(0.62 \mathrm{mmol})$, Pd-cat, solvent $(0.023 \mathrm{~mol} / \mathrm{L}), \mathrm{N}_{2}$ atmosphere, 2 h. PhMe: methylbenzene; DMF: dimethylformamide; $\mathrm{MeCN}$ : acetonitrile. ${ }^{b}$ Isolated yields. 
as the additive.

\subsection{Enzymatic activity}

The IDH1-R132H inhibitory potency of all target compounds was tested. In addition, the assay of inhibitory activity toward IDH1/WT was also conducted to determine the selectivity of the selected compounds. AG-120 was used as a reference compound in these assays. The results are listed in Tables 2 and 3.

Table 2 IDH1-R132H inhibitory activity of the target compounds $8 \mathbf{b}$ and $9 \mathbf{a} \sim 9 \mathbf{9}$

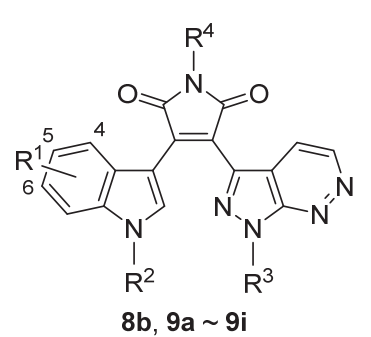

$8 b, 9 a \sim 9 i$

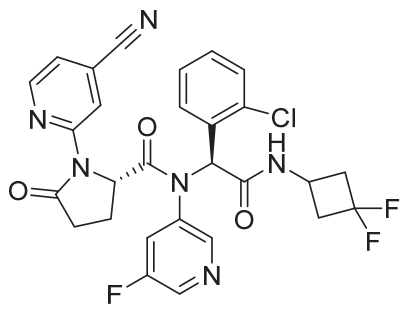

Ivosidenib (AG-120)

\begin{tabular}{|c|c|c|c|c|c|}
\hline Compd. & $\mathrm{R}^{1}$ & $\mathrm{R}^{2}$ & $\mathrm{R}^{3}$ & $\mathrm{R}^{4}$ & $\begin{array}{l}\mathrm{IC}_{50} \pm \mathrm{SE}^{a} / \\
\left(\mathrm{nmol} \cdot \mathrm{L}^{-1}\right)\end{array}$ \\
\hline $9 a$ & $\mathrm{H}$ & $\left(\mathrm{CH}_{2}\right)_{3} \mathrm{~N}$ & $\mathrm{Me}$ & $\mathrm{H}$ & $148 \pm 46$ \\
\hline $9 b$ & $6-\mathrm{Br}$ & $\left(\mathrm{CH}_{2}\right)_{3} \mathrm{~N}$ & $\mathrm{Me}$ & $\mathrm{H}$ & $31 \pm 2$ \\
\hline $9 \mathrm{c}$ & $6-\mathrm{F}$ & $\left(\mathrm{CH}_{2}\right)_{3} \mathrm{~N}$ & $\mathrm{Me}$ & $\mathrm{H}$ & $127 \pm 53$ \\
\hline 9d & $5-\mathrm{F}$ & $\left(\mathrm{CH}_{2}\right)_{3} \mathrm{~N}$ & $\mathrm{Me}$ & $\mathrm{H}$ & $84 \pm 31$ \\
\hline $9 e$ & 6-Me & $\left(\mathrm{CH}_{2}\right)_{3} \mathrm{~N}$ & $\mathrm{Me}$ & $\mathrm{H}$ & $42 \pm 12$ \\
\hline 9f & $6-\mathrm{Br}$ & $\left(\mathrm{CH}_{2}\right)_{3} \mathrm{~N}$ & Et & $\mathrm{H}$ & $37 \pm 3$ \\
\hline $9 \mathrm{~g}$ & $6-\mathrm{Br}$ & $\left(\mathrm{CH}_{2}\right)_{3} \mathrm{I}$ & $n$-Bu & $\mathrm{H}$ & $76 \pm 3$ \\
\hline $9 h$ & $6-\mathrm{Br}$ & $\mathrm{H}$ & $\mathrm{Me}$ & $\mathrm{H}$ & $1495 \pm 258$ \\
\hline $9 \mathbf{i}$ & $6-\mathrm{Br}$ & $\left(\mathrm{CH}_{2}\right)_{3} \mathrm{~N}$ & $\mathrm{Me}$ & $\mathrm{Me}$ & $351 \pm 23$ \\
\hline $8 b$ & $6-\mathrm{Br}$ & $\left(\mathrm{CH}_{2}\right)_{3} \mathrm{~N}$ & $\mathrm{Me}$ & $\mathrm{Ph}$ & $\geqslant 10000$ \\
\hline AG-120 & & & & & $199 \pm 81$ \\
\hline
\end{tabular}

${ }^{a} \mathrm{SE}$ : standard error mean.

Table 3 IDH1/WT inhibitory activity of selected compounds

\begin{tabular}{cc}
\hline Compd. & $\mathrm{IC}_{50} /\left(\mu \mathrm{mol} \cdot \mathrm{L}^{-1}\right)$ \\
\hline 9b & $\geqslant 10$ \\
9d & $\geqslant 10$ \\
9e & $\geqslant 10$ \\
9f & $\geqslant 10$ \\
$\mathbf{9 g}$ & $\geqslant 10$ \\
\hline
\end{tabular}

As shown in Table 2, most of the tested compound showed similar or more potent IDH1-R132H inhibitory activity in comparison with AG-120. Structure-activity relationship (SAR) analysis showed that introduction of a small hydrophobic group such as bromine $\left(9 \mathrm{~b}, \mathrm{IC}_{50}=31 \pm 2\right.$ $\mathrm{nmol} / \mathrm{L})$ and methyl $\left(9 \mathrm{e}, \mathrm{IC}_{50}=42 \pm 12 \mathrm{nmol} / \mathrm{L}\right)$ at the 6-position of indole ring led to about four-fold increase of the activity as compared to $9 \mathbf{a}\left(\mathrm{IC}_{50}=148 \pm 46 \mathrm{nmol} / \mathrm{L}\right)$. Fluorine at 5- or 6-position of the indole ring was tolerated for the activity.

Introduction of a 3-(1H-imidazol-1-yl)propyl on the indole nitrogen $\left(9 \mathbf{b}, \mathrm{IC}_{50}=31 \pm 2 \mathrm{nmol} / \mathrm{L}\right)$, which may form hydrogen bond with the protein, resulted in about 50 -fold enhancement of the activity as compared to $9 \mathbf{h}\left(\mathrm{IC}_{50}=\right.$ $1495 \pm 258 \mathrm{nmol} / \mathrm{L})$. A small hydrophobic methyl $(\mathbf{9 b})$ or ethyl $\left(9 \mathrm{f}, \mathrm{IC}_{50}=37 \pm 3 \mathrm{nmol} / \mathrm{L}\right)$ on $\mathrm{N}^{1}$-position of the pyrazolo[3,4-c]pyridazine ring was tolerated for the activity. However, replacement of methyl or ethyl with a larger butyl $\left(9 \mathrm{~g}, \mathrm{IC}_{50}=76 \pm 3 \mathrm{nmol} / \mathrm{L}\right)$ led to some loss in IDH1-R132H potency. Comparison of the inhibitory activity of $\mathbf{9 b}$ with 8b $\left(\mathrm{IC}_{50} \geqslant 10000 \mathrm{nmol} / \mathrm{L}\right)$ and $9 \mathbf{i}\left(\mathrm{IC}_{50}=351 \pm 23 \mathrm{nmol} / \mathrm{L}\right)$ revealed that the $\mathrm{NH}$ of the imide moiety is important for the activity. The data in Table 3 revealed that all the selected compounds $9 \mathrm{~b}, 9 \mathrm{~d}, 9 \mathrm{e}, 9 \mathrm{f}$ and $9 \mathrm{~g}$ showed high selectivity on IDH1/WT.

\subsection{Cellular activity}

IDH1 mutants catalyze the conversion of $\alpha-\mathrm{KG}$ to $2-\mathrm{HG}$. Currently, 2-HG is used as a biomarker for IDH1 mutants. ${ }^{[25-27]}$ Therefore, the down-regulation of intracellular 2-HG by a compound is the most direct indicator of the inhibition of IDH1 mutants. Using AG-120 as a reference, the ability of compounds $\mathbf{9 b}, \mathbf{9 f}$ and $\mathbf{9 g}$ to reduce $2-\mathrm{HG}$ production in U87MG cells was investigated using a LCMS/MS method. As shown in Figure 2, at a concentration of $10 \mu \mathrm{mol} / \mathrm{L}$, compounds $\mathbf{9 b}, \mathbf{9 f}$ and $\mathbf{9 g}$ effectively inhibited the production of 2-HG in U87MG cells expressing IDH1R132H. Compound 9b had the highest activity with an inhibition rate of $87 \%$. In addition, the activity of the compound was dependent on the concentration. When the

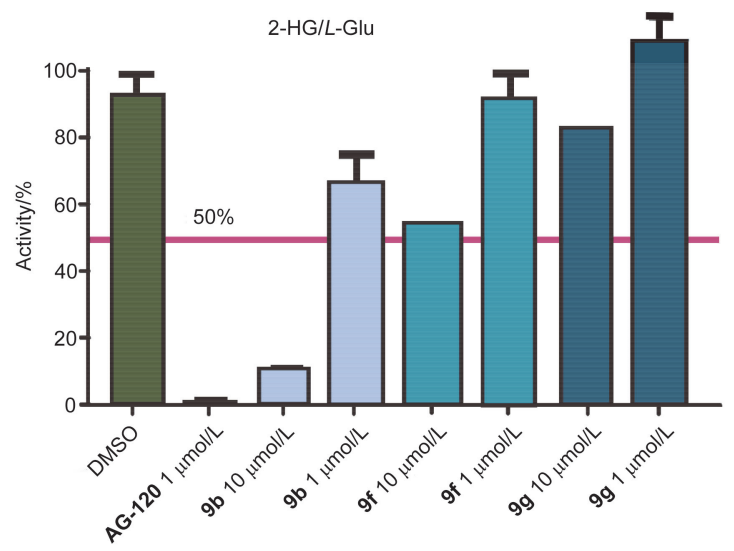

Figure 2 Selected compounds inhibited 2-HG production in IDH1-R132H expressing U87MG cells 
concentration was reduced to $1 \mu \mathrm{mol} / \mathrm{L}$, the activity was decreased significantly. Unfortunately, although compounds $9 \mathrm{~b}, 9 \mathrm{f}$ and $9 \mathrm{~g}$ had better inhibitory activity toward IDH1-R132H than the positive control AG-120, the ability of the compounds to inhibit 2-HG production in cells was significantly lower than that of AG-120. This relatively low cellular activity may be because of an insufficient ability of the designed compounds to penetrate cells.

\subsection{Molecular modeling study}

To investigate the possible binding patterns of compound 9b to IDH1-R132H, molecular docking was performed using the reported IDH1-R132H structure (PDB ID: 5DE1) by using the CDOCKER module (Discovery Studio, version 2.5; Accelrys, San Diego, CA, USA, 2008). Docking results showed that the CDOCKER ENERGY of compound $9 \mathbf{b}(-75.8 \mathrm{~kJ} / \mathrm{mol})$ was lower than that of ligand $(-56.9$ $\mathrm{kJ} / \mathrm{mol}$ ) in protein $5 \mathrm{DE} 1$, indicating a stronger binding affinity. Then we outputted the results using pymol 1.8. Figure 3 clearly shows that the $\mathrm{NH}$ and carbonyl groups on the maleimide ring of $\mathbf{9 b}$ can form important interactions with the hinge region residues Ile128 and Ala111 of IDH1-R132H via a hydrogen bond network. The nitrogen atom at the 6 th and 7 th positions in the pyrazolo[3,4c]pyridazine moiety of compound $\mathbf{9 b}$ acts as a hydrogen bond acceptor to form two other hydrogen bonds with Arg119. And the methyl group was inserted into a smaller hydrophobic pocket consisting of Arg119 and Trp124. The indole moiety of compound $\mathbf{9 b}$ has a $\pi-\pi$ interaction (T-shaped) with the Trp124 residue. In addition, the 6-position bromine atom on the indole ring can be inserted into a hydrophobic pocket composed of Val255 and Met259 which is similar to that reported by Ref. [28]. Finally, the 3-position nitrogen of the imidazole ring is closer to the $\mathrm{NH}$ of Arg119 and Leu120, which makes it possible for the $\mathrm{N}$ atom to interact with Arg119 and Leu120 via a water bridge.

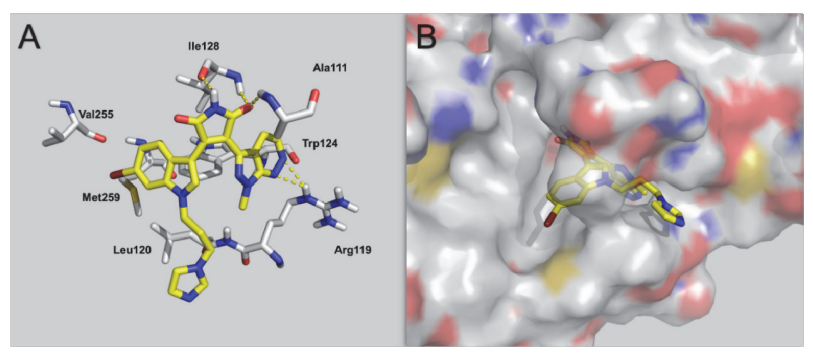

Figure 3 Docking of $\mathbf{9 b}$ to IDH1-R132H crystal structure

\section{Conclusions}

Ten novel 3-(indol-3-yl)-4-(pyrazolo[3,4-c]pyridazin-3yl)maleimide IDH1-R132H inhibitors were designed and synthesized. Compounds 9b, 9d, 9e, 9f and 9g showed strong inhibitory activity to IDH1-R132H and good selectivity to wild-type IDH1. Compound $9 \mathbf{b}$ could effectively inhibit the production of $2-\mathrm{HG}$ in U87MG cells expressing IDH1-R132H. Studies of the structure-activity relationship and the protein binding patterns provided theoretical guid- ance for further researches.

\section{Experimental section}

\subsection{Instruments and reagents}

All reagents used in the synthesis were obtained commercially and used without further purification, unless otherwise specified. Melting points were determined with a BüCHI Melting Point B-450 apparatus (Büchi Labortechnik, Flawil, Switzerland) and are uncorrected. ${ }^{1} \mathrm{H}$ NMR spectra were recorded using TMS as the internal standard at $500 \mathrm{MHz}$ and the coupling constants are reported in $\mathrm{Hz}$. The reactions were followed by thin-layer chromatography (TLC) on glass-packed precoated silica gel plates and visualized in an iodine chamber or with a UV lamp. Tetrahydrofuran (THF) was distilled from sodium-benzophenone. DMF was distilled from calcium hydride. Preparation methods and physicochemical properties for compounds $\mathbf{6 a} \sim \mathbf{6 e}$ were reported in Ref. [22].

\subsection{Synthesis}

\subsubsection{Synthesis of 2}

To a mixture of $1 H$-pyrazolo[3,4-c]pyridazin-3-amine (1, $11.0 \mathrm{~g}, 81 \mathrm{mmol})$, concentrated hydrochloric acid (68 $\mathrm{mL})$ and water $(40 \mathrm{~mL})$, a solution of $\mathrm{NaNO}_{2}(6.2 \mathrm{~g}, 90$ mmol) in water $(90 \mathrm{~mL})$ was added dropwise at $0 \sim 5{ }^{\circ} \mathrm{C}$. After addition, the mixture was stirred for additional $30 \mathrm{~min}$ at that temperature. After that, appropriate amount of urea was added to destroy the excess $\mathrm{NaNO}_{2}$. The resulted mixture was added in batches to a solution of KI (46.0 g, $280 \mathrm{mmol})$ in water $(300 \mathrm{~mL})$ at room temperature and then stirred for another $8 \mathrm{~h}$. Then the mixture was adjusted to weakly alkaline with saturated $\mathrm{NaHCO}_{3}$ solution, filtered and washed with water. The filter cake was dried in vacuum to afford 3-iodo-1 $H$-pyrazolo[3,4-c]pyri- dazine (2) (12.0 g, $60.0 \%)$ as a brown solid, m.p. $238 \sim 240{ }^{\circ} \mathrm{C} .{ }^{1} \mathrm{H}$ NMR $(500$ MHz, DMSO- $\left.d_{6}\right) \delta: 14.91(\mathrm{~s}, 1 \mathrm{H}), 9.18(\mathrm{~d}, J=5.5 \mathrm{~Hz}, 1 \mathrm{H})$, $7.91(\mathrm{~d}, J=5.6 \mathrm{~Hz}, 1 \mathrm{H})$; ESI-MS $m / z: 247[\mathrm{M}+\mathrm{H}]^{+}$.

\subsubsection{Synthesis of $\mathbf{3}$}

To a solution of $2(6.0 \mathrm{~g}, 24 \mathrm{mmol})$ in dry tetrahydrofuran (THF) $(500 \mathrm{~mL}), \mathrm{EtMgBr}(48 \mathrm{mmol})$ in dry $\mathrm{Et}_{2} \mathrm{O}(48 \mathrm{~mL})$ was added dropwise at $-5 \sim 0{ }^{\circ} \mathrm{C}$. After stirring for 30 min, a solution of $\mathrm{Sn}(\mathrm{Bu})_{3} \mathrm{Cl}(19.5 \mathrm{~g}, 60 \mathrm{mmol})$ in dry THF $(15 \mathrm{~mL})$ was added dropwise to the mixture at $-5 \sim 0{ }^{\circ} \mathrm{C}$. The reaction mixture was stirred at $-5 \sim 0{ }^{\circ} \mathrm{C}$ for $1 \mathrm{~h}$, then at room temperature for $1 \mathrm{~h}$. The mixture was poured into $\mathrm{NH}_{4} \mathrm{Cl}$ saturation solution $(500 \mathrm{~mL})$, and extracted with EtOAc $(300 \mathrm{~mL} \times 3)$. The combined organic layers were washed with brine, dried over $\mathrm{Na}_{2} \mathrm{SO}_{4}$, concentrated in vacuum and purified by flash column chromatography on silica gel using petroleum ether/ethyl acetate $(V: V=2: 1)$ to afford 3-(tributylstannyl)-1 $H$-pyrazolo[3,4-c]pyridazine $(3)^{[22]}(2.6 \mathrm{~g}, 38.6 \%)$ as a yellow liquid. ${ }^{1} \mathrm{H}$ NMR $(500 \mathrm{MHz}$, $\left.\mathrm{CDCl}_{3}\right) \delta: 12.62(\mathrm{~s}, 1 \mathrm{H}), 9.12(\mathrm{~d}, J=5.5 \mathrm{~Hz}, 1 \mathrm{H}), 7.86(\mathrm{~d}$, $J=5.5 \mathrm{~Hz}, 1 \mathrm{H}), 1.72 \sim 1.52(\mathrm{~m}, 6 \mathrm{H}), 1.38 \sim 1.27(\mathrm{~m}, 12 \mathrm{H})$, $0.90(\mathrm{t}, J=7.3 \mathrm{~Hz}, 9 \mathrm{H})$; MS (ESI) $m / z: 411[\mathrm{M}+\mathrm{H}]^{+}$. Anal. calcd for $\mathrm{C}_{17} \mathrm{H}_{30} \mathrm{~N}_{4} \mathrm{Sn}$ : C 49.90, H 7.39, N 13.69; found C 
49.76, H 7.63, N 13.57.

\subsubsection{Synthesis of $\mathbf{4}$}

To a solution of $3(2.2 \mathrm{~g}, 5.3 \mathrm{mmol})$ in dry $N, N$-dimethylformamide (DMF) $(40 \mathrm{~mL}), 60 \% \mathrm{NaH}(0.24 \mathrm{~g}, 6.0$ mmol) was added in batches at $0 \sim 5{ }^{\circ} \mathrm{C}$, and the mixture was then stirred for another $0.5 \mathrm{~h}$ at that temperature. After that, $\mathrm{CH}_{3} \mathrm{I}(0.91 \mathrm{~g}, 6.4 \mathrm{mmol})$ was added and stirred at room temperature for $1 \mathrm{~h}$. The resulted mixture was poured into water $(300 \mathrm{~mL})$, extracted with dichloromethane (DCM) $(100 \mathrm{~mL} \times 3)$ and the combined organic layers were washed with brine, dried over $\mathrm{Na}_{2} \mathrm{SO}_{4}$, concentrated in vacuum and purified by flash column chromatography on silica gel using petroleum ether/ethyl acetate $(V: V=4: 1)$ to afford 1 methyl-3-(tributylstannyl)-1 $H$-pyrazolo[3,4-c]pyridazine (4a) $(1.5 \mathrm{~g}, 67.5 \%)$ as a yellow liquid. ${ }^{1} \mathrm{H}$ NMR (500 MHz, $\left.\mathrm{CDCl}_{3}\right) \delta$ : $9.05(\mathrm{~d}, J=5.5 \mathrm{~Hz}, 1 \mathrm{H}), 7.76(\mathrm{~d}, J=5.5 \mathrm{~Hz}, 1 \mathrm{H})$, $4.39(\mathrm{~s}, 3 \mathrm{H}), 1.64 \sim 1.56(\mathrm{~m}, 6 \mathrm{H}), 1.42 \sim 1.31(\mathrm{~m}, 12 \mathrm{H})$, 0.89 (t, $J=7.3 \mathrm{~Hz}, 9 \mathrm{H})$; MS (ESI) $m / z: 425[\mathrm{M}+\mathrm{H}]^{+}$. Anal. calcd for $\mathrm{C}_{18} \mathrm{H}_{32} \mathrm{~N}_{4} \mathrm{Sn}$ : C 51.09, H 7.62, N 13.24; found $\mathrm{C}$ 51.17, H 7.72, N 13.08.

1-Ethyl-3-(tributylstannyl)-1H-pyrazolo[3,4-c]pyridazine (4b): Reaction of 3 with bromoethane afforded $\mathbf{4 b}$ in $45.8 \%$ yield as a yellow liquid. ${ }^{1} \mathrm{H} \mathrm{NMR}\left(500 \mathrm{MHz}, \mathrm{CDCl}_{3}\right)$ $\delta: 9.04(\mathrm{~d}, J=5.5 \mathrm{~Hz}, 1 \mathrm{H}), 7.75(\mathrm{~d}, J=5.5 \mathrm{~Hz}, 1 \mathrm{H}), 4.84$ (q, $J=7.2 \mathrm{~Hz}, 2 \mathrm{H}), 1.65 \sim 1.60(\mathrm{~m}, 6 \mathrm{H}), 1.56(\mathrm{t}, J=7.2 \mathrm{~Hz}$, $3 \mathrm{H}), 1.40 \sim 1.23(\mathrm{~m}, 12 \mathrm{H}), 0.89(\mathrm{t}, J=7.3 \mathrm{~Hz}, 9 \mathrm{H}) ; \mathrm{MS}$ (ESI) $m / z: 439[\mathrm{M}+\mathrm{H}]^{+}$. Anal. calcd for $\mathrm{C}_{19} \mathrm{H}_{34} \mathrm{~N}_{4} \mathrm{Sn}: \mathrm{C}$ 52.20, H 7.84, N 12.81; found C 52.33, H 7.75, N 12.66.

1-Butyl-3-(tributylstannyl)-1H-pyrazolo[3,4-c]pyridazine $(\mathbf{4 c})$ : Reaction of 3 with bromobutane afforded $4 \mathbf{c}$ in $52.4 \%$ yield as a yellow liquid. ${ }^{1} \mathrm{H} \mathrm{NMR}\left(500 \mathrm{MHz}, \mathrm{CDCl}_{3}\right)$ $\delta: 9.04(\mathrm{~d}, J=5.5 \mathrm{~Hz}, 1 \mathrm{H}), 7.76(\mathrm{~d}, J=5.6 \mathrm{~Hz}, 1 \mathrm{H}), 4.79(\mathrm{t}$, $J=7.2 \mathrm{~Hz}, 2 \mathrm{H}), 2.08 \sim 1.98(\mathrm{~m}, 2 \mathrm{H}), 1.70 \sim 1.50(\mathrm{~m}, 6 \mathrm{H})$, $1.43 \sim 1.18(\mathrm{~m}, 14 \mathrm{H}), 0.97(\mathrm{t}, J=7.4 \mathrm{~Hz}, 3 \mathrm{H}), 0.89(\mathrm{t}, J=$ $7.3 \mathrm{~Hz}, 9 \mathrm{H}$ ); MS (ESI) $\mathrm{m} / z: 467[\mathrm{M}+\mathrm{H}]^{+}$. Anal. calcd for $\mathrm{C}_{21} \mathrm{H}_{38} \mathrm{~N}_{4} \mathrm{Sn}$ : C 54.21, H 8.23, N 12.04; found C 54.40, H $8.15, \mathrm{~N} 12.22$.

\subsubsection{Synthesis of 7}

Under a nitrogen atmosphere, a mixture of $\mathbf{4 a}(240 \mathrm{mg}$, $0.57 \mathrm{mmol}), 6 \mathbf{a}(201 \mathrm{mg}, 0.62 \mathrm{mmol}), \mathrm{Pd}\left(\mathrm{Ph}_{3}\right)_{2} \mathrm{Cl}_{2}(60 \mathrm{mg}$, $0.085 \mathrm{mmol})$ and $\mathrm{LiCl}(55 \mathrm{mg}, 1.30 \mathrm{mmol})$ in dry 1,4-dioxane $(25 \mathrm{~mL})$ was stirred at $100{ }^{\circ} \mathrm{C}$ for $2 \mathrm{~h}$. After cooling, the mixture was poured into water $(50 \mathrm{~mL})$, and then extracted with EtOAc $(50 \mathrm{~mL} \times 3)$. The combined organic layer was washed with brine, dried over $\mathrm{Na}_{2} \mathrm{SO}_{4}$, concentrated in vacuum and purified by flash column chromatography on silica gel using petroleum ether/ethyl acetate $(V: V=4: 1)$ to give 3-(1H-indol-3-yl)-4-(1-methyl-1H-pyrazolo[3,4-c]pyridazin-3-yl)-1-phenyl- $1 H$-pyrrole-2,5-dione (7a) $(202 \mathrm{mg}, 94.5 \%)$ as a red solid. m.p. $238 \sim 240{ }^{\circ} \mathrm{C} ;{ }^{1} \mathrm{H} \mathrm{NMR}\left(500 \mathrm{MHz}, \mathrm{CDCl}_{3}\right) \delta: 12.13(\mathrm{~s}, 1 \mathrm{H})$, $9.15(\mathrm{~d}, J=5.7 \mathrm{~Hz}, 1 \mathrm{H}), 8.30(\mathrm{~d}, J=3.0 \mathrm{~Hz}, 1 \mathrm{H}), 8.05$ (d, $J=5.7 \mathrm{~Hz}, 1 \mathrm{H}), 7.60 \sim 7.52(\mathrm{~m}, 5 \mathrm{H}), 7.50 \sim 7.41(\mathrm{~m}, 2 \mathrm{H})$, $6.81 \sim 6.73(\mathrm{~m}, 1 \mathrm{H}), 6.37(\mathrm{~d}, J=8.0 \mathrm{~Hz}, 1 \mathrm{H}), 4.21(\mathrm{~s}, 3 \mathrm{H})$; MS (ESI) $m / z: 421[\mathrm{M}+\mathrm{H}]^{+}$. Anal. calcd for $\mathrm{C}_{24} \mathrm{H}_{16} \mathrm{~N}_{6} \mathrm{O}_{2}$ : C 68.56, H 3.84, N 19.99; found C 68.43, H 3.61, N 20.09.
3-(6-Bromo-1H-indol-3-yl)-4-(1-methyl-1 $H$-pyrazolo[3, 4-c]pyridazin-3-yl)-1-phenyl-1 $H$-pyrrole-2,5-dione (7b): Reaction of $4 \mathbf{a}$ with $\mathbf{6 b}$ afforded $7 \mathbf{b}$ in $44.6 \%$ yield as a red solid. m.p. 122 124 ${ }^{\circ} \mathrm{C}$; ${ }^{1} \mathrm{H}$ NMR (500 MHz, DMSO-d $)$ $\delta: 12.17(\mathrm{~s}, 1 \mathrm{H}), 9.18(\mathrm{~d}, J=5.7 \mathrm{~Hz}, 1 \mathrm{H}), 8.31(\mathrm{~d}, J=2.1$ $\mathrm{Hz}, 1 \mathrm{H}), 8.08$ (d, $J=5.6 \mathrm{~Hz}, 1 \mathrm{H}), 7.67$ (d, $J=1.8 \mathrm{~Hz}, 1 \mathrm{H})$, $7.60 \sim 7.52(\mathrm{~m}, 4 \mathrm{H}), 7.50 \sim 7.42(\mathrm{~m}, 1 \mathrm{H}), 6.98(\mathrm{dd}, J=8.6$, $1.9 \mathrm{~Hz}, 1 \mathrm{H}), 6.47$ (d, $J=8.6 \mathrm{~Hz}, 1 \mathrm{H}), 4.24$ (s, 3H); MS (ESI) $m / z$ : $499[\mathrm{M}+\mathrm{H}]^{+}$. Anal. calcd for $\mathrm{C}_{24} \mathrm{H}_{15} \mathrm{BrN}_{6} \mathrm{O}_{2}: \mathrm{C}$ 57.73, H 3.03, N 16.83; found C 57.88, H 3.15, N 16.96.

3-(6-Fluoro-1H-indol-3-yl)-4-(1-methyl-1H-pyrazolo[3, 4-c]pyridazin-3-yl)-1-phenyl-1 $H$-pyrrole-2,5-dione (7c): Reaction of $\mathbf{4 a}$ with $\mathbf{6 c}$ afforded $\mathbf{7 c}$ in $72.7 \%$ yield as a red solid. m.p. $>250{ }^{\circ} \mathrm{C} ;{ }^{1} \mathrm{H}$ NMR (500 MHz, DMSO- $\left.d_{6}\right) \delta$ : $12.13(\mathrm{~s}, 1 \mathrm{H}), 9.18$ (d, $J=5.6 \mathrm{~Hz}, 1 \mathrm{H}), 8.30$ (d, $J=2.9 \mathrm{~Hz}$, $1 \mathrm{H}), 8.09$ (d, $J=5.6 \mathrm{~Hz}, 1 \mathrm{H}), 7.59 \sim 7.53(\mathrm{~m}, 4 \mathrm{H}), 7.50 \sim$ $7.42(\mathrm{~m}, 1 \mathrm{H}), 7.27(\mathrm{dd}, J=9.6,2.5 \mathrm{~Hz}, 1 \mathrm{H}), 6.70(\mathrm{dd}, J=$ 9.3, $2.4 \mathrm{~Hz}, 1 \mathrm{H}), 6.49 \sim 6.43(\mathrm{~m}, 1 \mathrm{H}), 4.23(\mathrm{~s}, 3 \mathrm{H})$; MS (ESI) $m / z$ : $439[\mathrm{M}+\mathrm{H}]^{+}$. Anal. calcd for $\mathrm{C}_{24} \mathrm{H}_{15} \mathrm{FN}_{6} \mathrm{O}_{2}$ : C 65.75, H 3.45, N 19.17; found C 65.90, H 3.52, N 19.02.

3-(5-Fluoro-1H-indol-3-yl)-4-(1-methyl-1H-pyrazolo[3, 4-c]pyridazin-3-yl)-1-phenyl-1H-pyrrole-2,5-dione (7d): Reaction of $\mathbf{4 a}$ with $\mathbf{6 d}$ afforded $\mathbf{7 d}$ in $58.4 \%$ yield as a red solid. m.p. $>250{ }^{\circ} \mathrm{C} ;{ }^{1} \mathrm{H}$ NMR (500 MHz, DMSO- $\left.d_{6}\right) \delta$ : $12.19(\mathrm{~s}, 1 \mathrm{H}), 9.20(\mathrm{~d}, J=5.7 \mathrm{~Hz}, 1 \mathrm{H}), 8.37(\mathrm{~d}, J=3.1 \mathrm{~Hz}$, $1 \mathrm{H}), 8.10(\mathrm{~d}, J=5.6 \mathrm{~Hz}, 1 \mathrm{H}), 7.59 \sim 7.53(\mathrm{~m}, 4 \mathrm{H}), 7.52 \sim$ $7.42(\mathrm{~m}, 2 \mathrm{H}), 6.96 \sim 7.00(\mathrm{~m}, 1 \mathrm{H}), 6.24(\mathrm{dd}, J=10.7,2.5$ $\mathrm{Hz}, 1 \mathrm{H}), 4.26$ (s, 3H); MS (ESI) $m / z: 439[\mathrm{M}+\mathrm{H}]^{+}$. Anal. calcd for $\mathrm{C}_{24} \mathrm{H}_{15} \mathrm{FN}_{6} \mathrm{O}_{2}$ : C 65.75, H 3.45, N 19.17; found $\mathrm{C}$ 65.82, H 3.61, N 19.23.

3-(6-Methyl-1H-indol-3-yl)-4-(1-methyl- $1 H$-pyrazolo[3, 4-c]pyridazin-3-yl)-1-phenyl-1H-pyrrole-2,5-dione (7e): Reaction of $4 \mathbf{a}$ with $6 \mathrm{e}$ afforded $7 \mathrm{e}$ in $67.6 \%$ yield as a red solid. m.p. $>250{ }^{\circ} \mathrm{C} ;{ }^{1} \mathrm{H}$ NMR $\left(500 \mathrm{MHz}, \mathrm{DMSO}-d_{6}\right) \delta$ : $12.00(\mathrm{~s}, 1 \mathrm{H}), 9.15$ (d, $J=5.6 \mathrm{~Hz}, 1 \mathrm{H}), 8.25(\mathrm{~s}, 1 \mathrm{H}), 8.03$ (d, $J=5.6 \mathrm{~Hz}, 1 \mathrm{H}), 7.60 \sim 7.52(\mathrm{~m}, 4 \mathrm{H}), 7.48 \sim 7.43(\mathrm{~m}, 1 \mathrm{H})$, $7.26(\mathrm{~s}, 1 \mathrm{H}), 6.60(\mathrm{dd}, J=8.4,1.5 \mathrm{~Hz}, 1 \mathrm{H}), 6.22(\mathrm{~d}, J=8.2$ $\mathrm{Hz}, 1 \mathrm{H}), 4.24$ (s, 3H), 2.32 (s, 3H); MS (ESI) $m / z: 435$ $[\mathrm{M}+\mathrm{H}]^{+}$. Anal. calcd for $\mathrm{C}_{25} \mathrm{H}_{18} \mathrm{~N}_{6} \mathrm{O}_{2}$ : C 69.11, H 4.18, N 19.34; found C 68.96, H 4.33, N 19.51.

3-(6-Bromo-1H-indol-3-yl)-4-(1-ethyl-1H-pyrazolo[3,4c]pyridazin-3-yl)-1-phenyl-1H-pyrrole-2,5-dione (7f): Reaction of $\mathbf{4 b}$ with $\mathbf{6 b}$ afforded $7 \mathbf{f}$ in $50.4 \%$ yield as a red solid. m.p. $152 \sim 153{ }^{\circ} \mathrm{C} ;{ }^{1} \mathrm{H}$ NMR $\left(500 \mathrm{MHz}\right.$, DMSO- $\left.d_{6}\right)$ $\delta: 12.17(\mathrm{~s}, 1 \mathrm{H}), 9.22$ (d, $J=5.6 \mathrm{~Hz}, 1 \mathrm{H}), 8.30$ (d, $J=3.0$ $\mathrm{Hz}, 1 \mathrm{H}), 8.19$ (d, $J=5.7 \mathrm{~Hz}, 1 \mathrm{H}), 7.68$ (d, $J=1.9 \mathrm{~Hz}, 1 \mathrm{H})$, $7.58 \sim 7.55(\mathrm{~m}, 4 \mathrm{H}), 7.49 \sim 7.42(\mathrm{~m}, 1 \mathrm{H}), 6.95(\mathrm{dd}, J=8.6$, $1.9 \mathrm{~Hz}, 1 \mathrm{H}), 6.44$ (d, $J=8.6 \mathrm{~Hz}, 1 \mathrm{H}), 4.67$ (q, $J=7.2 \mathrm{~Hz}$, $2 \mathrm{H}), 1.33(\mathrm{t}, J=7.2 \mathrm{~Hz}, 3 \mathrm{H})$; MS (ESI) $m / z: 513[\mathrm{M}+\mathrm{H}]^{+}$; Anal. calcd for $\mathrm{C}_{25} \mathrm{H}_{17} \mathrm{BrN}_{6} \mathrm{O}_{2}$ : C 58.49, $\mathrm{H}$ 3.34, N 16.37; found $\mathrm{C} 58.63$, H 3.21, N 16.49.

3-(6-Bromo-1H-indol-3-yl)-4-(1-butyl- $1 H$-pyrazolo[3,4c]pyridazin-3-yl)-1-phenyl-1H-pyrrole-2,5-dione (7g): Reaction of $\mathbf{4 c}$ with $\mathbf{6 b}$ afforded $7 \mathbf{g}$ in $49.1 \%$ yield as a red solid. m.p. 220 221 ${ }^{\circ} \mathrm{C}$; ${ }^{1} \mathrm{H}$ NMR (500 MHz, DMSO-d $)$ $\delta: 12.16(\mathrm{~d}, J=3.0 \mathrm{~Hz}, 1 \mathrm{H}), 9.22(\mathrm{~d}, J=5.6 \mathrm{~Hz}, 1 \mathrm{H}), 8.26$ $(\mathrm{d}, J=3.0 \mathrm{~Hz}, 1 \mathrm{H}), 8.19(\mathrm{~d}, J=5.6 \mathrm{~Hz}, 1 \mathrm{H}), 7.68(\mathrm{~d}, J=$ 
$1.8 \mathrm{~Hz}, 1 \mathrm{H}), 7.60 \sim 7.52(\mathrm{~m}, 4 \mathrm{H}), 7.49 \sim 7.42(\mathrm{~m}, 1 \mathrm{H}), 6.90$ $(\mathrm{dd}, J=8.5,1.9 \mathrm{~Hz}, 1 \mathrm{H}), 6.40(\mathrm{~d}, J=8.6 \mathrm{~Hz}, 1 \mathrm{H}), 4.62(\mathrm{t}$, $J=6.9 \mathrm{~Hz}, 2 \mathrm{H}), 1.69 \sim 1.62(\mathrm{~m}, 2 \mathrm{H}), 1.23 \sim 1.10(\mathrm{~m}, 2 \mathrm{H})$, $0.84(\mathrm{t}, J=7.4 \mathrm{~Hz}, 3 \mathrm{H})$; MS (ESI) $m / z: 541[\mathrm{M}+\mathrm{H}]^{+}$; Anal. calcd for $\mathrm{C}_{27} \mathrm{H}_{21} \mathrm{BrN}_{6} \mathrm{O}_{2}$ : C 59.90, H 3.91, N 15.52; found $\mathrm{C}$ 59.99, H 4.01, N 15.43.

\subsubsection{Synthesis of $\mathbf{8}$}

To a solution of $7 \mathbf{a}(120 \mathrm{mg}, 0.21 \mathrm{mmol})$ in dry DMF (30 $\mathrm{mL}), 60 \% \mathrm{NaH}(13 \mathrm{mg}, 0.32 \mathrm{mmol})$ was added at room temperature, and the mixture was stirred for $30 \mathrm{~min}$. 1-(3-Chloropropyl)- $1 H$-imidazole (61 $\mathrm{mg}, 0.42 \mathrm{mmol}$ ) was added and the mixture was stirred at $75{ }^{\circ} \mathrm{C}$ for $6 \mathrm{~h}$. After cooling, the resulted mixture was poured into water (200 $\mathrm{mL})$ and then extracted with EtOAc $(100 \mathrm{~mL} \times 3)$. The combined organic layers were washed with brine, dried over $\mathrm{Na}_{2} \mathrm{SO}_{4}$, concentrated in vacuum and purified by flash column chromatography on silica gel using DCM/MeOH/ Triethylamine (TEA) $(V: V: V=120: 2: 1)$ to afford 3-(1-(3-(1H-imi- dazol-1-yl)propyl)-1H-indol-3-yl)-4-(1methyl-1H-pyrazolo[3,4-c]pyridazin-3-yl)-1-phenyl- $1 H$ pyrrole-2,5-dione (8a) (50 mg, 33.1\%) as a red solid. m.p. $240 \sim 242{ }^{\circ} \mathrm{C}$; ${ }^{1} \mathrm{H}$ NMR $\left(500 \mathrm{MHz}, \mathrm{DMSO}-d_{6}\right) \delta: 9.16(\mathrm{~d}$, $J=5.6 \mathrm{~Hz}, 1 \mathrm{H}), 8.36(\mathrm{~s}, 1 \mathrm{H}), 8.08(\mathrm{~d}, J=5.6 \mathrm{~Hz}, 1 \mathrm{H}), 7.71$ $(\mathrm{s}, 1 \mathrm{H}), 7.58 \sim 7.55(\mathrm{~m}, 4 \mathrm{H}), 7.52(\mathrm{~d}, J=8.2 \mathrm{~Hz}, 1 \mathrm{H})$, $7.48 \sim 7.43(\mathrm{~m}, 1 \mathrm{H}), 7.27(\mathrm{~d}, J=1.4 \mathrm{~Hz}, 1 \mathrm{H}), 7.17(\mathrm{t}, J=7.8$ $\mathrm{Hz}, 1 \mathrm{H}), 6.96(\mathrm{~s}, 1 \mathrm{H}), 6.86(\mathrm{t}, J=7.6 \mathrm{~Hz}, 1 \mathrm{H}), 6.54(\mathrm{~d}, J=$ $8.1 \mathrm{~Hz}, 1 \mathrm{H}), 4.32$ (t, $J=7.3 \mathrm{~Hz}, 2 \mathrm{H}), 4.22(\mathrm{~s}, 3 \mathrm{H}), 4.07$ (t, $J=7.1 \mathrm{~Hz}, 2 \mathrm{H}), 2.36 \sim 2.30(\mathrm{~m}, 2 \mathrm{H})$; MS (ESI) $\mathrm{m} / \mathrm{z}: 529$ $[\mathrm{M}+\mathrm{H}]^{+}$. Anal. calcd for $\mathrm{C}_{30} \mathrm{H}_{24} \mathrm{~N}_{8} \mathrm{O}_{2}: \mathrm{C} 68.17, \mathrm{H} 4.58, \mathrm{~N}$ 21.20; found C 68.28, H 4.42, N 21.34.

3-(1-(3-(1H-Imidazol-1-yl)propyl)-6-bromo- $1 H$-indol-3yl)-4-(1-methyl-1H-pyrazolo[3,4-c]pyrida-zin-3-yl)-1-phen yl-1H-pyrrole-2,5-dione (8b): Reaction of 7b with 1-(3chloropropyl)- $1 H$-imidazole afforded $\mathbf{8 b}$ in $38.0 \%$ yield as a red solid. m.p. $108 \sim 110{ }^{\circ} \mathrm{C} ;{ }^{1} \mathrm{H}$ NMR $(500 \mathrm{MHz}$, DMSO- $\left.d_{6}\right) \delta: 9.22(\mathrm{~d}, J=5.6 \mathrm{~Hz}, 1 \mathrm{H}), 8.33(\mathrm{~s}, 1 \mathrm{H}), 8.20(\mathrm{~d}$, $J=5.7 \mathrm{~Hz}, 1 \mathrm{H}), 7.86(\mathrm{~d}, J=1.8 \mathrm{~Hz}, 1 \mathrm{H}), 7.84(\mathrm{~s}, 1 \mathrm{H})$, $7.61 \sim 7.53(\mathrm{~m}, 4 \mathrm{H}), 7.50 \sim 7.42(\mathrm{~m}, 1 \mathrm{H}), 7.31(\mathrm{~d}, J=1.5$ $\mathrm{Hz}, 1 \mathrm{H}), 7.04 \sim 7.01(\mathrm{~m}, 2 \mathrm{H}), 6.55(\mathrm{~d}, J=8.6 \mathrm{~Hz}, 1 \mathrm{H}), 4.33$ (t, $J=7.4 \mathrm{~Hz}, 2 \mathrm{H}), 4.24$ (s, 3H), 4.09 (t, $J=7.2 \mathrm{~Hz}, 2 \mathrm{H})$, $2.36 \sim 2.31(\mathrm{~m}, 2 \mathrm{H})$; MS (ESI) $m / z: 607[\mathrm{M}+\mathrm{H}]^{+}$. Anal. calcd for $\mathrm{C}_{30} \mathrm{H}_{23} \mathrm{BrN}_{8} \mathrm{O}_{2}$ : C 59.32, $\mathrm{H} 3.82, \mathrm{~N} \mathrm{18.45}$; found $\mathrm{C}$ 59.44, H 3.75, N 18.49 .

3-(1-(3-(1H-Imidazol-1-yl)propyl)-6-fluoro-1H-indol-3yl)-4-(1-methyl-1H-pyrazolo[3,4-c]pyridazin-3-yl)-1-phenyl-1H-pyrrole-2,5-dione (8c): Reaction of 7c with 1-(3chloropropyl)- $1 H$-imidazole afforded $\mathbf{8 c}$ in $33.8 \%$ yield as a red solid. m.p. $199 \sim 201{ }^{\circ} \mathrm{C} ;{ }^{1} \mathrm{H}$ NMR $(500 \mathrm{MHz}$, DMSO- $\left.d_{6}\right) \delta: 9.19(\mathrm{~d}, J=5.6 \mathrm{~Hz}, 1 \mathrm{H}), 8.41(\mathrm{~s}, 1 \mathrm{H}), 8.11(\mathrm{~d}$, $J=5.6 \mathrm{~Hz}, 1 \mathrm{H}), 7.66(\mathrm{~s}, 1 \mathrm{H}), 7.60 \sim 7.52(\mathrm{~m}, 5 \mathrm{H}), 7.50 \sim$ $7.41(\mathrm{~m}, 1 \mathrm{H}), 7.23(\mathrm{~s}, 1 \mathrm{H}), 7.06(\mathrm{td}, J=9.1,2.6 \mathrm{~Hz}, 1 \mathrm{H})$, $6.93(\mathrm{~s}, 1 \mathrm{H}), 6.44(\mathrm{dd}, J=10.5,2.6 \mathrm{~Hz}, 1 \mathrm{H}), 4.30(\mathrm{t}, J=7.3$ $\mathrm{Hz}, 2 \mathrm{H}), 4.25$ (s, 3H), 4.03 (t, $J=7.2 \mathrm{~Hz}, 2 \mathrm{H}), 2.34 \sim 2.28$ $(\mathrm{m}, 2 \mathrm{H})$; MS (ESI) $\mathrm{m} / \mathrm{z}: 547[\mathrm{M}+\mathrm{H}]^{+}$; Anal. calcd for $\mathrm{C}_{30} \mathrm{H}_{23} \mathrm{FN}_{8} \mathrm{O}_{2}$ : C 65.93, H 4.24, N 20.50; found $\mathrm{C} 66.06, \mathrm{H}$ 4.49, N 20.38 .
3-(1-(3-(1H-Imidazol-1-yl)propyl)-5-fluoro-1 $H$-indol-3yl)-4-(1-methyl-1H-pyrazolo[3,4-c]pyrida-zin-3-yl)-1-phen yl-1H-pyrrole-2,5-dione (8d): Reaction of 7d with 1-(3-chloropropyl)-1 $H$-imidazole afforded $\mathbf{8 d}$ in $39.3 \%$ yield as a red solid. m.p. $188 \sim 190{ }^{\circ} \mathrm{C} ;{ }^{1} \mathrm{H}$ NMR $(500 \mathrm{MHz}$, DMSO- $\left.d_{6}\right) \delta: 9.19(\mathrm{~d}, J=5.6 \mathrm{~Hz}, 1 \mathrm{H}), 8.41(\mathrm{~s}, 1 \mathrm{H}), 8.11(\mathrm{~d}$, $J=5.6 \mathrm{~Hz}, 1 \mathrm{H}), 7.66(\mathrm{~s}, 1 \mathrm{H}), 7.56(\mathrm{t}, J=3.7 \mathrm{~Hz}, 5 \mathrm{H})$, $7.43 \sim 7.47(\mathrm{~m}, 1 \mathrm{H}), 7.23(\mathrm{~d}, J=1.3 \mathrm{~Hz}, 1 \mathrm{H}), 7.04 \sim 7.08$ $(\mathrm{m}, 2.6 \mathrm{~Hz}, 1 \mathrm{H}), 6.93(\mathrm{t}, J=1.1 \mathrm{~Hz}, 1 \mathrm{H}), 6.44(\mathrm{dd}, J=10.5$, $2.6 \mathrm{~Hz}, 1 \mathrm{H}), 4.30(\mathrm{t}, J=7.3 \mathrm{~Hz}, 2 \mathrm{H}), 4.25(\mathrm{~s}, 3 \mathrm{H}), 4.03(\mathrm{t}$, $J=7.2 \mathrm{~Hz}, 2 \mathrm{H}), 2.27 \sim 2.32(\mathrm{~m}, 2 \mathrm{H})$; MS (ESI) $\mathrm{m} / z: 547$ $[\mathrm{M}+\mathrm{H}]^{+}$; Anal. calcd for $\mathrm{C}_{30} \mathrm{H}_{23} \mathrm{FN}_{8} \mathrm{O}_{2}: \mathrm{C} 65.93, \mathrm{H} 4.24, \mathrm{~N}$ 20.50; found C 65.89, H 4.38, N 20.45.

3-(1-(3-(1H-Imidazol-1-yl)propyl)-6-methyl- $1 H$-indol3-yl)-4-(1-methyl-1H-pyrazolo[3,4-c]pyridazin-3-yl)-1phenyl-1H-pyrrole-2,5-dione (8e): Reaction of $7 \mathbf{e}$ with 1-(3-chloropropyl)-1 $H$-imidazole afforded $8 \mathbf{e}$ in $42.2 \%$ yield as a red solid. m.p. $108 \sim 110{ }^{\circ} \mathrm{C} ;{ }^{1} \mathrm{H}$ NMR $(500 \mathrm{MHz}$, DMSO- $\left.d_{6}\right) \delta: 9.16(\mathrm{~d}, J=5.7 \mathrm{~Hz}, 1 \mathrm{H}), 8.30(\mathrm{~s}, 1 \mathrm{H}), 8.06(\mathrm{~d}$, $J=5.6 \mathrm{~Hz}, 1 \mathrm{H}), 7.91(\mathrm{~s}, 1 \mathrm{H}), 7.58 \sim 7.54(\mathrm{~m}, 4 \mathrm{H}), 7.51 \sim$ $7.41(\mathrm{~m}, 1 \mathrm{H}), 7.37 \sim 7.32(\mathrm{~m}, 1 \mathrm{H}), 7.30(\mathrm{~s}, 1 \mathrm{H}), 7.06(\mathrm{~s}$, $1 \mathrm{H}), 6.68(\mathrm{dd}, J=8.4,1.4 \mathrm{~Hz}, 1 \mathrm{H}), 6.37(\mathrm{~d}, J=8.2 \mathrm{~Hz}, 1 \mathrm{H})$, 4.29 (t, $J=7.3 \mathrm{~Hz}, 2 \mathrm{H}), 4.24(\mathrm{~s}, 3 \mathrm{H}), 4.10(\mathrm{t}, J=7.1 \mathrm{~Hz}$, $2 \mathrm{H}), 2.38 \sim 2.26(\mathrm{~m}, 5 \mathrm{H})$; MS (ESI) $m / z: 543[\mathrm{M}+\mathrm{H}]^{+}$. Anal. calcd for $\mathrm{C}_{31} \mathrm{H}_{26} \mathrm{~N}_{8} \mathrm{O}_{2}$ : C 68.62, $\mathrm{H} \mathrm{4.83,} \mathrm{N} \mathrm{20.65;}$ found $\mathrm{C} 68.84, \mathrm{H} 4.76, \mathrm{~N} 20.52$.

3-(1-(3-(1H-Imidazol-1-yl)propyl)-6-bromo- $1 H$-indol-3yl)-4-(1-ethyl-1H-pyrazolo[3,4-c]pyridazin-3-yl)-1-phenyl$1 \mathrm{H}$-pyrrole-2,5-dione (8f): Reaction of $7 \mathbf{f}$ with 1-(3-chloropropyl)- $1 H$-imidazole afforded $\mathbf{8 f}$ in $39.1 \%$ yield as a red solid. m.p. $116 \sim 118{ }^{\circ} \mathrm{C} ;{ }^{1} \mathrm{H}$ NMR (500 MHz, DMSO- $\left.d_{6}\right)$ $\delta: 9.22(\mathrm{~d}, J=5.6 \mathrm{~Hz}, 1 \mathrm{H}), 8.33(\mathrm{~s}, 1 \mathrm{H}), 8.20(\mathrm{~d}, J=5.7 \mathrm{~Hz}$, $1 \mathrm{H}), 7.86(\mathrm{~d}, J=1.8 \mathrm{~Hz}, 1 \mathrm{H}), 7.84(\mathrm{~s}, 1 \mathrm{H}), 7.61 \sim 7.53(\mathrm{~m}$, 4H), $7.50 \sim 7.42(\mathrm{~m}, 1 \mathrm{H}), 7.31(\mathrm{~d}, J=1.5 \mathrm{~Hz}, 1 \mathrm{H}), 7.04 \sim$ $7.01(\mathrm{~m}, 2 \mathrm{H}), 6.55(\mathrm{~d}, J=8.6 \mathrm{~Hz}, 1 \mathrm{H}), 4.67$ (q, $J=7.3 \mathrm{~Hz}$, $2 \mathrm{H}), 4.33(\mathrm{t}, J=7.4 \mathrm{~Hz}, 2 \mathrm{H}), 4.09(\mathrm{t}, J=7.2 \mathrm{~Hz}, 2 \mathrm{H})$, $2.35 \sim 2.31(\mathrm{~m}, 2 \mathrm{H}), 1.32(\mathrm{t}, J=7.2 \mathrm{~Hz}, 3 \mathrm{H})$; $\mathrm{MS}(\mathrm{ESI}) \mathrm{m} / \mathrm{z}$ : $621[\mathrm{M}+\mathrm{H}]^{+}$. Anal. calcd for $\mathrm{C}_{31} \mathrm{H}_{25} \mathrm{BrN}_{8} \mathrm{O}_{2}$ : C 59.91, $\mathrm{H}$ 4.05, N 18.03; found C 59.76, H 4.15, N 18.22.

3-(1-(3-(1H-Imidazol-1-yl)propyl)-6-bromo-1H-indol-3yl)-4-(1-butyl-1H-pyrazolo[3,4-c]pyridazin-3-yl)-1-phenyl -1H-pyrrole-2,5-dione (8g): According to procedure used to prepare $\mathbf{8 a}$, the reaction of $\mathbf{7 g}$ with 1-(3-chloropropyl)$1 \mathrm{H}$-imidazole afforded $\mathbf{8 g}$ in $38.2 \%$ yield as a red solid. m.p. $187 \sim 189{ }^{\circ} \mathrm{C}$; ${ }^{1} \mathrm{H}$ NMR (500 MHz, DMSO- $\left.d_{6}\right) \delta: 9.22(\mathrm{~d}$, $J=5.7 \mathrm{~Hz}, 1 \mathrm{H}), 8.28(\mathrm{~s}, 1 \mathrm{H}), 8.21(\mathrm{~d}, J=5.7 \mathrm{~Hz}, 1 \mathrm{H}), 7.86$ $(\mathrm{d}, J=1.8 \mathrm{~Hz}, 1 \mathrm{H}), 7.68(\mathrm{~s}, 1 \mathrm{H}), 7.60 \sim 7.52(\mathrm{~m}, 4 \mathrm{H})$, $7.50 \sim 7.42(\mathrm{~m}, 1 \mathrm{H}), 7.24(\mathrm{~s}, 1 \mathrm{H}), 6.97(\mathrm{dd}, J=8.6,1.7 \mathrm{~Hz}$, $1 \mathrm{H}), 6.94(\mathrm{~s}, 1 \mathrm{H}), 6.49(\mathrm{~d}, J=8.6 \mathrm{~Hz}, 1 \mathrm{H}), 4.61(\mathrm{t}, J=6.9$ $\mathrm{Hz}, 2 \mathrm{H}), 4.32$ (t, $J=7.4 \mathrm{~Hz}, 2 \mathrm{H}), 4.05(\mathrm{t}, J=7.1 \mathrm{~Hz}, 2 \mathrm{H})$, $2.34 \sim 2.29(\mathrm{~m}, 2 \mathrm{H}), 1.66 \sim 1.61(\mathrm{~m}, 2 \mathrm{H}), 1.22 \sim 1.09(\mathrm{~m}$, $2 \mathrm{H}), 0.81(\mathrm{t}, J=7.3 \mathrm{~Hz}, 3 \mathrm{H})$; MS (ESI) $m / z: 649[\mathrm{M}+\mathrm{H}]^{+}$. Anal. calcd for $\mathrm{C}_{33} \mathrm{H}_{29} \mathrm{BrN}_{8} \mathrm{O}_{2}$ : C 61.02, $\mathrm{H} 4.50, \mathrm{~N} 17.25$; found $\mathrm{C} 61.23, \mathrm{H} 4.38, \mathrm{~N} 17.43$.

\subsubsection{Synthesis of 9}

Under a nitrogen atmosphere, 8a (50 mg, $0.097 \mathrm{mmol})$ 
was reacted with $\mathrm{NH}_{4} \mathrm{OAc}(8.0 \mathrm{~g}, 104 \mathrm{mmol})$ at $140{ }^{\circ} \mathrm{C}$ for $6 \mathrm{~h}$. After cooling, the resulted mixture was poured into water $(50 \mathrm{~mL})$, alkalified by $\mathrm{NaHCO}_{3}$ solution and extracted with EtOAc $(50 \mathrm{~mL} \times 3)$. The combined organic layers were washed with brine, dried over $\mathrm{Na}_{2} \mathrm{SO}_{4}$, concentrated in vacuum and purified by flash column chromatography on silica gel using DCM/MeOH/TEA $(V: V$ : $V=120: 4: 1)$ to give 3-(1-(3-(1H-imidazol-1yl)propyl)-1 $H$-indol-3-yl)-4-(1-methyl- $1 H$-pyrazolo[3,4-c] pyridazin-3-yl)-1H-pyrrole-2,5-dione (9a) (38 mg, 86.4\%) as a red solid. m.p. $108 \sim 110{ }^{\circ} \mathrm{C} ;{ }^{1} \mathrm{H}$ NMR $(500 \mathrm{MHz}$, $\left.\mathrm{CDCl}_{3}\right) \delta: 11.48(\mathrm{~s}, 1 \mathrm{H}), 9.25(\mathrm{~d}, J=5.6 \mathrm{~Hz}, 1 \mathrm{H}), 8.70(\mathrm{~s}$, $1 \mathrm{H}), 8.40(\mathrm{~s}, 1 \mathrm{H}), 8.13(\mathrm{~d}, J=5.6 \mathrm{~Hz}, 1 \mathrm{H}), 7.71(\mathrm{~s}, 1 \mathrm{H}), 7.65$ $(\mathrm{d}, J=8.2 \mathrm{~Hz}, 1 \mathrm{H}), 7.51(\mathrm{~s}, 1 \mathrm{H}), 7.26(\mathrm{~d}, J=7.6 \mathrm{~Hz}, 1 \mathrm{H})$, $6.92(\mathrm{t}, J=7.6 \mathrm{~Hz}, 1 \mathrm{H}), 6.51(\mathrm{~d}, J=8.1 \mathrm{~Hz}, 1 \mathrm{H}), 4.47(\mathrm{t}$, $J=7.4 \mathrm{~Hz}, 2 \mathrm{H}), 4.34(\mathrm{t}, J=7.2 \mathrm{~Hz}, 2 \mathrm{H}), 4.30(\mathrm{~s}, 3 \mathrm{H})$, $2.53 \sim 2.48(\mathrm{~m}, 2 \mathrm{H})$; MS (ESI) $m / z: 453[\mathrm{M}+\mathrm{H}]^{+}$. Anal. calcd for $\mathrm{C}_{24} \mathrm{H}_{20} \mathrm{~N}_{8} \mathrm{O}_{2}$ : C 63.71, H 4.46, N 24.76; found $\mathrm{C}$ 63.59, H 4.73, N 24.87.

3-(1-(3-(1H-Imidazol-1-yl)propyl)-6-bromo-1H-indol-3yl)-4-(1-methyl-1H-pyrazolo[3,4-c]pyridazin-3-yl)-1H-pyrrole-2,5-dione (9b): Reaction of $\mathbf{8 b}$ with $\mathrm{NH}_{4} \mathrm{OAc}$ afforded 9b in $77.8 \%$ yield as a red solid. m.p. $115 \sim 117{ }^{\circ} \mathrm{C} ;{ }^{1} \mathrm{H}$ NMR (500 MHz, DMSO- $\left.d_{6}\right) \delta: 11.40(\mathrm{~s}, 1 \mathrm{H}), 9.15$ (d, $J=$ $5.6 \mathrm{~Hz}, 1 \mathrm{H}), 8.26(\mathrm{~s}, 1 \mathrm{H}), 8.03(\mathrm{~d}, J=5.6 \mathrm{~Hz}, 1 \mathrm{H}), 7.83(\mathrm{~s}$, $1 \mathrm{H}), 7.82(\mathrm{~d}, J=1.8 \mathrm{~Hz}, 1 \mathrm{H}), 7.31(\mathrm{~s}, 1 \mathrm{H}), 7.03 \sim 6.99(\mathrm{~m}$, $2 \mathrm{H}), 6.49(\mathrm{~d}, J=8.6 \mathrm{~Hz}, 1 \mathrm{H}), 4.30(\mathrm{t}, J=7.4 \mathrm{~Hz}, 2 \mathrm{H})$, $4.21(\mathrm{~s}, 3 \mathrm{H}), 4.08(\mathrm{t}, J=7.2 \mathrm{~Hz}, 2 \mathrm{H}), 2.33 \sim 2.98(\mathrm{~m}, 2 \mathrm{H})$; MS (ESI) $m / z: 531[\mathrm{M}+\mathrm{H}]^{+}$. Anal. calcd for $\mathrm{C}_{24} \mathrm{H}_{19} \mathrm{Br}-$ $\mathrm{N}_{8} \mathrm{O}_{2}$ : C 54.25, H 3.60, N 21.09; found C 54.27, H 3.78, N 21.33.

3-(1-(3-(1H-Imidazol-1-yl)propyl)-6-fluoro-1H-indol-3yl)-4-(1-methyl-1 $H$-pyrazolo[3,4-c]pyridazin-3-yl)-1 $H$-pyrrole-2,5-dione (9c): Reaction of $\mathbf{8 c}$ with $\mathrm{NH}_{4} \mathrm{OAc}$ afforded 9c in $81.5 \%$ yield as a red solid. m.p. $174 \sim 176{ }^{\circ} \mathrm{C} ;{ }^{1} \mathrm{H}$ NMR (500 MHz, DMSO- $\left.d_{6}\right) \delta: 11.39(\mathrm{~s}, 1 \mathrm{H}), 9.16$ (d, $J=$ $5.6 \mathrm{~Hz}, 1 \mathrm{H}), 8.73(\mathrm{~s}, 1 \mathrm{H}), 8.27(\mathrm{~s}, 1 \mathrm{H}), 8.05(\mathrm{~d}, J=5.6 \mathrm{~Hz}$, $1 \mathrm{H}), 7.65(\mathrm{~s}, 1 \mathrm{H}), 7.53 \sim 7.44(\mathrm{~m}, 2 \mathrm{H}), 6.79 \sim 6.65(\mathrm{~m}, 1 \mathrm{H})$, $6.49 \sim 6.44(\mathrm{~m}, 1 \mathrm{H}), 4.34(\mathrm{t}, J=7.3 \mathrm{~Hz}, 2 \mathrm{H}), 4.24(\mathrm{t}, J=7.2$ $\mathrm{Hz}, 2 \mathrm{H}), 4.20$ (s, 3H), 2.40 2.35 (m, 2H); MS (ESI) $m / z$ : $471[\mathrm{M}+\mathrm{H}]^{+}$. Anal. calcd for $\mathrm{C}_{24} \mathrm{H}_{19} \mathrm{FN}_{8} \mathrm{O}_{2}: \mathrm{C} 61.27, \mathrm{H}$ 4.07, N 23.82; found C 61.36, H 4.22, N 23.65.

3-(1-(3-(1H-Imidazol-1-yl)propyl)-5-fluoro- $1 H$-indol-3yl)-4-(1-methyl-1H-pyrazolo[3,4-c]pyridazin-3-yl)-1 $H$-pyrrole-2,5-dione (9d): Reaction of $\mathbf{8 d}$ with $\mathrm{NH}_{4} \mathrm{OAc}$ afforded 9d in $79.8 \%$ yield as a red solid. m.p. $151 \sim 153{ }^{\circ} \mathrm{C} ;{ }^{1} \mathrm{H}$ NMR (500 MHz, DMSO- $\left.d_{6}\right) \delta: 11.30(\mathrm{~s}, 1 \mathrm{H}), 9.17$ (d, $J=$ $5.7 \mathrm{~Hz}, 1 \mathrm{H}), 8.33(\mathrm{~s}, 1 \mathrm{H}), 8.06(\mathrm{~d}, J=5.6 \mathrm{~Hz}, 1 \mathrm{H}), 7.67$ (s, $1 \mathrm{H}), 7.56 \sim 7.52(\mathrm{~m}, 1 \mathrm{H}), 7.24(\mathrm{~s}, 1 \mathrm{H}), 7.03(\mathrm{td}, J=9.1,2.6$ $\mathrm{Hz}, 1 \mathrm{H}), 6.94$ (s, 1H), 6.29 (dd, $J=10.5,2.6 \mathrm{~Hz}, 1 \mathrm{H}), 4.28$ (t, $J=7.3 \mathrm{~Hz}, 2 \mathrm{H}), 4.22$ (s, 3H), 4.04 (t, $J=7.2 \mathrm{~Hz}, 2 \mathrm{H})$, $2.31 \sim 2.27(\mathrm{~m}, 2 \mathrm{H})$; MS (ESI) $m / z: 471[\mathrm{M}+\mathrm{H}]^{+}$. Anal. calcd for $\mathrm{C}_{24} \mathrm{H}_{19} \mathrm{FN}_{8} \mathrm{O}_{2}$ : C 61.27, $\mathrm{H}$ 4.07, $\mathrm{N} 23.82$; found $\mathrm{C}$ 61.20, H 4.10, N 23.99 .

3-(1-(3-(1H-Imidazol-1-yl)propyl)-6-methyl- $1 H$-indol3-yl)-4-(1-methyl-1H-pyrazolo[3,4-c]pyridazin-3-yl)- $1 H$ pyrrole-2,5-dione (9e): Reaction of $8 \mathbf{e}$ with $\mathrm{NH}_{4} \mathrm{OAc}$ afforded $8 \mathbf{e}$ in $83.8 \%$ yield as a red solid. m.p. $115 \sim$ $117{ }^{\circ} \mathrm{C} ;{ }^{1} \mathrm{H}$ NMR (500 MHz, DMSO-d 6$) \delta: 11.31(\mathrm{~s}, 1 \mathrm{H})$, $9.12(\mathrm{~d}, J=5.6 \mathrm{~Hz}, 1 \mathrm{H}), 8.21(\mathrm{~s}, 1 \mathrm{H}), 7.99(\mathrm{~d}, J=5.7 \mathrm{~Hz}$, $1 \mathrm{H}), 7.95(\mathrm{~s}, 1 \mathrm{H}), 7.36(\mathrm{~s}, 1 \mathrm{H}), 7.27(\mathrm{~s}, 1 \mathrm{H}), 7.08(\mathrm{~s}, 1 \mathrm{H})$, $6.63(\mathrm{dd}, J=8.4,1.5 \mathrm{~Hz}, 1 \mathrm{H}), 6.25(\mathrm{~d}, J=8.2 \mathrm{~Hz}, 1 \mathrm{H}), 4.26$ (t, $J=7.3 \mathrm{~Hz}, 2 \mathrm{H}), 4.20$ (s, 3H), 4.09 (t, $J=7.1 \mathrm{~Hz}, 2 \mathrm{H})$, $2.36 \sim 2.26(\mathrm{~m}, 5 \mathrm{H})$; MS (ESI) $m / z: 467[\mathrm{M}+\mathrm{H}]^{+}$. Anal.

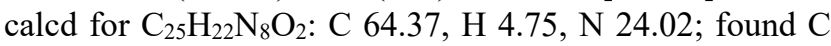
64.21, H 4.66, N 23.81.

3-(1-(3-(1H-Imidazol-1-yl)propyl)-6-bromo-1H-indol-3yl)-4-(1-ethyl-1 $H$-pyrazolo[3,4-c]pyridazin-3-yl)- $H$ pyrrole-2,5-dione (9f): Reaction of $8 \mathbf{f}$ with $\mathrm{NH}_{4} \mathrm{OAc}$ afforded 9f in 82.9\% yield as a red solid. m.p. 127 $\sim 129{ }^{\circ} \mathrm{C}$; ${ }^{1} \mathrm{H}$ NMR (500 MHz, DMSO-d $) \delta: 11.37$ (s, 1H), 9.19 (d, $J=5.7 \mathrm{~Hz}, 1 \mathrm{H}), 8.23(\mathrm{~s}, 1 \mathrm{H}), 8.13(\mathrm{~d}, J=5.7 \mathrm{~Hz}, 1 \mathrm{H}), 7.81$ $(\mathrm{d}, J=1.8 \mathrm{~Hz}, 1 \mathrm{H}), 7.68(\mathrm{~s}, 1 \mathrm{H}), 7.25(\mathrm{~s}, 1 \mathrm{H}), 6.97$ (dd, $J=$ $8.6,1.8 \mathrm{~Hz}, 1 \mathrm{H}), 6.93(\mathrm{~s}, 1 \mathrm{H}), 6.43(\mathrm{~d}, J=8.6 \mathrm{~Hz}, 1 \mathrm{H}), 4.63$ (q, $J=7.2 \mathrm{~Hz}, 2 \mathrm{H}), 4.28(\mathrm{t}, J=7.4 \mathrm{~Hz}, 2 \mathrm{H}), 4.05(\mathrm{t}, J=7.2$ $\mathrm{Hz}, 2 \mathrm{H}), 2.30 \sim 2.26(\mathrm{~m}, J=7.2 \mathrm{~Hz}, 2 \mathrm{H}), 1.28(\mathrm{t}, J=7.2 \mathrm{~Hz}$, $3 \mathrm{H}$ ); MS (ESI) $m / z$ : $545[\mathrm{M}+\mathrm{H}]^{+}$. Anal. calcd for $\mathrm{C}_{25} \mathrm{H}_{21} \mathrm{BrN}_{8} \mathrm{O}_{2}$ : C 55.06, H 3.88, N 20.55; found C 54.96, $\mathrm{H}$ 3.64, N 20.66.

3-(1-(3-(1H-Imidazol-1-yl)propyl)-6-bromo-1H-indol-3yl)-4-(1-butyl-1H-p-yrazolo[3,4-c]pyridazin-3-yl)-1H-pyrole-2,5-dione (9g): Reaction of $\mathbf{8 g}$ with $\mathrm{NH}_{4} \mathrm{OAc}$ afforded 9g in $87.3 \%$ yield as a red solid. m.p. $125 \sim 127{ }^{\circ} \mathrm{C} ;{ }^{1} \mathrm{H}$ NMR $\left(500 \mathrm{MHz}, \mathrm{DMSO}-d_{6}\right) \delta: 11.37(\mathrm{~s}, 1 \mathrm{H}), 9.19(\mathrm{~d}, J=$ $5.6 \mathrm{~Hz}, 1 \mathrm{H}), 8.18(\mathrm{~s}, 1 \mathrm{H}), 8.15(\mathrm{~d}, J=5.6 \mathrm{~Hz}, 1 \mathrm{H}), 7.82$ (d, $J=1.8 \mathrm{~Hz}, 1 \mathrm{H}), 7.77(\mathrm{~s}, 1 \mathrm{H}), 7.28(\mathrm{~s}, 1 \mathrm{H}), 6.98(\mathrm{~s}, 1 \mathrm{H}), 6.91$ $(\mathrm{dd}, J=8.6,1.7 \mathrm{~Hz}, 1 \mathrm{H}), 6.36(\mathrm{~d}, J=8.6 \mathrm{~Hz}, 1 \mathrm{H}), 4.57(\mathrm{t}$, $J=6.9 \mathrm{~Hz}, 2 \mathrm{H}), 4.29(\mathrm{t}, J=7.4 \mathrm{~Hz}, 2 \mathrm{H}), 4.06(\mathrm{t}, J=7.2 \mathrm{~Hz}$, $2 \mathrm{H}), 2.31 \sim 2.27(\mathrm{~m}, 2 \mathrm{H}), 1.62 \sim 1.57(\mathrm{~m}, 2 \mathrm{H}), 1.16 \sim 1.08$ (m, 2H), 0.79 (t, $J=7.4 \mathrm{~Hz}, 3 \mathrm{H})$; MS (ESI) $\mathrm{m} / z$ : $545[\mathrm{M}+$ $\mathrm{H}]^{+}$. Anal. calcd for $\mathrm{C}_{27} \mathrm{H}_{25} \mathrm{BrN}_{8} \mathrm{O}_{2}$ : C 56.55, $\mathrm{H} 4.39, \mathrm{~N}$ 19.54; found C 56.81, H 4.51, N 19.73.

3-(6-Bromo-1H-indol-3-yl)-4-(1-methyl-1H-pyrazolo[3,4-c]pyridazin-3-yl)-1H-pyrrole-2,5-dione (9h): Reaction of $7 \mathbf{b}$ with $\mathrm{NH}_{4} \mathrm{OAc}$ afforded $\mathbf{9 h}$ in $81.2 \%$ yield as a red solid. m.p. $>250{ }^{\circ} \mathrm{C} ;{ }^{1} \mathrm{H}$ NMR $\left(500 \mathrm{MHz}, \mathrm{DMSO}-d_{6}\right) \delta$ : $12.10(\mathrm{~s}, 1 \mathrm{H}), 11.34(\mathrm{~s}, 1 \mathrm{H}), 9.15(\mathrm{~d}, J=5.6 \mathrm{~Hz}, 1 \mathrm{H}), 8.22$ $(\mathrm{d}, J=2.9 \mathrm{~Hz}, 1 \mathrm{H}), 8.01(\mathrm{~d}, J=5.6 \mathrm{~Hz}, 1 \mathrm{H}), 7.64(\mathrm{~d}, J=1.9$ $\mathrm{Hz}, 1 \mathrm{H}), 6.93$ (dd, $J=8.6,1.9 \mathrm{~Hz}, 1 \mathrm{H}), 6.37$ (d, $J=8.7 \mathrm{~Hz}$, $1 \mathrm{H}), 4.21(\mathrm{~s}, 3 \mathrm{H})$; MS (ESI) $m / z: 423[\mathrm{M}+\mathrm{H}]^{+}$. Anal. calcd

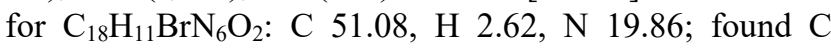
51.22, H 2.54, N 19.66 .

3-(1-(3-(1H-Imidazol-1-yl)propyl)-6-bromo-1 $H$-indol-3yl)-4-(1-methyl-1H-pyrazolo[3,4-c]pyridazin-3-yl)-1-methyl-1H-pyrrole-2,5-dione (9i): Compound $8 \mathbf{b}(30.0 \mathrm{mg}$, $0.049 \mathrm{mmol})$ was reacted with a solution of $\mathrm{CH}_{3} \mathrm{NH}_{2}$ in methanol $(30 \%, 30 \mathrm{~mL})$ at room temperature for $2 \mathrm{~h}$. The solvent was concentrated in vacuum and the residue was purified by flash column chromatography on silica gel using $\mathrm{DCM} / \mathrm{MeOH} / \mathrm{TEA}(V: V: V=120: 4: 1)$ to afford $9 \mathrm{i}$ (22 mg, 81.5\%) as a red solid. m.p. $144 \sim 146{ }^{\circ} \mathrm{C} ;{ }^{1} \mathrm{H}$ NMR $\left(500 \mathrm{MHz}, \mathrm{DMSO}-d_{6}\right) \delta: 9.16(\mathrm{~d}, J=5.6 \mathrm{~Hz}, 1 \mathrm{H}), 8.30$ (s, $1 \mathrm{H}), 8.03(\mathrm{~d}, J=5.6 \mathrm{~Hz}, 1 \mathrm{H}), 7.83(\mathrm{~d}, J=1.8 \mathrm{~Hz}, 1 \mathrm{H}), 7.69$ (s, $1 \mathrm{H}), 7.28 \sim 7.23(\mathrm{~m}, 1 \mathrm{H}), 7.03(\mathrm{dd}, J=8.6,1.7 \mathrm{~Hz}, 1 \mathrm{H})$, 
$6.94(\mathrm{~s}, 1 \mathrm{H}), 6.56(\mathrm{~d}, J=8.7 \mathrm{~Hz}, 1 \mathrm{H}), 4.30(\mathrm{t}, J=7.3 \mathrm{~Hz}$, $2 \mathrm{H}), 4.22(\mathrm{~s}, 3 \mathrm{H}), 4.05(\mathrm{t}, J=7.2 \mathrm{~Hz}, 2 \mathrm{H}), 3.10(\mathrm{~s}, 3 \mathrm{H})$, $2.32 \sim 2.25(\mathrm{~m}, 2 \mathrm{H})$; MS (ESI) $m / z: 545[\mathrm{M}+\mathrm{H}]^{+}$. Anal. calcd for $\mathrm{C}_{25} \mathrm{H}_{21} \mathrm{BrN}_{8} \mathrm{O}_{2}$ : C 55.06, H 3.88, N 20.55; found $\mathrm{C}$ 55.21, H 3.63, N 20.71.

\subsection{Biochemical assays}

\subsubsection{IDH1 mutations inhibition assay}

All recombinant human IDH1 mutations protein (IDH1/R132H, IDH1/R132C and IDH1/R132L), fused at the N-terminus to GST, were expressed in E. coli and purified using GST affinity column chromatography (QIAGEN). Enzyme inhibition assay for IDH1 mutations were performed in a 384-well microplate in $25 \mathrm{mmol} / \mathrm{L}$ Tris- $\mathrm{HCl}$ buffer (pH 7.0) containing the enzyme $(20 \sim 40 \mathrm{nmol} / \mathrm{L}), 8$ $\mathrm{mmol} / \mathrm{L} \mathrm{MnCl}_{2}, 12 \mu \mathrm{mol} / \mathrm{L} \mathrm{NADPH}$, and compounds. Upon incubation for $15 \mathrm{~min}, 1 \mathrm{mmol} / \mathrm{L} \alpha-\mathrm{KG}$ was added to initiate the reaction. And the decrease of NADPH was detected by Envision, at $355 \mathrm{~nm}$ excitation and $460 \mathrm{~nm}$ Emission (PerkinElmer). The $\mathrm{IC}_{50}$ data was calculated using the software GraphPad Prism, and chosen the equation "sigmoidal dose-response (variable slope)" for curve fitting.

\subsubsection{IDH1/WT inhibition assay}

Recombinant human IDH1/WT fused at the N-terminus to GST and expressed. The inhibition assay of IDH1/WT was carried out in $25 \mathrm{mmol} / \mathrm{L}$ Tris- $\mathrm{HCl}$ buffer $(\mathrm{pH} 7.0)$ containing the enzyme (30 nmol/L), $1 \mathrm{mmol} / \mathrm{L} \mathrm{MgCl}_{2}, 75$ $\mu \mathrm{mol} / \mathrm{L}$ NADP, an inhibitor, and $100 \mu \mathrm{mol} / \mathrm{L}$ sodium $(D)$-isocitrate. And the NADPH of probe was detected by monitoring the increase of fluorescence with Envision (PerkinElmer), at $355 \mathrm{~nm}$ excitation and $460 \mathrm{~nm}$ Emission. The $\mathrm{IC}_{50}$ data was calculated using the software GraphPad Prism, and chosen the equation "sigmoidal dose-response (variable slope)" for curve fitting.

4.3.3 U87MG IDH1-R132H-pruo Cell-based Assays and LC-MS/MS measurement of 2-HG

$\mathrm{R} 132 \mathrm{H}$ mutations were introduced into human IDH1 by standard molecular biology techniques. Human glioma U87MG cell lines were transfected using standard techniques. U87MG IDH1-R132H-puro cells were maintained in DMEM containing, 10\% FBS, $100 \mathrm{U} / \mathrm{mL}$ penicillin and $100 \mu \mathrm{g} / \mathrm{mL}$ streptomycin. Cells were seeded at a density of 20000 cells/well into 96-well microtiter plates and incubated overnight at $37{ }^{\circ} \mathrm{C}$ and $5 \% \mathrm{CO}_{2}$. The next day compounds were prepared in $100 \%$ dimethyl sulfoxide (DMSO) and then diluted in medium for a final concentration of $0.2 \%$ DMSO. Medium was removed from the cell plates, and 200 $\mu \mathrm{L}$ of the compound dilutions were added to each well. After $48 \mathrm{~h}$ of incubation with compound at $37{ }^{\circ} \mathrm{C}$, medium was removed from each well and pelleted cells were washed twice with ice-cold PBS before sequential quenching with $-80{ }^{\circ} \mathrm{C} \quad 80 \%$ methanol $/ 20 \%$ water. Intracellular $2-\mathrm{HG}$ and $L$-glutamic acid were measured by LC-MS/MS.

Supporting Information ${ }^{1} \mathrm{H}$ NMR of compounds $\mathbf{2} \sim \mathbf{9 i}$. The Supporting Information is available free of charge via the Internet at http://sioc-journal.cn.

\section{References}

[1] Dang, L.; White, D. W.; Gross, S.; Bennett, B. D.; Bittinger, M. A.; Driggers, E. M.; Fantin, V. R.; Jang, H. G.; Jin, S. Nature 2009, 462, 739 .

[2] Yan, H.; Parsons. D. W.; Jin, G. L.; McLendon, R.; Rasheed, B. A.; Yuan, W. S.; Kos, I.; Batinic-Haberle, I.; Jones, S.; Riggins, G. J.; Friedman, H.; Friedman, A.; Reardon, D.; Herndon, J.; Kinzler, K. W.; Velculescu, V. E.; Vogelstein, B.; Bigner, D. D. N. Engl. J. Med. 2009, 360, 765 .

[3] Dang, L.; Jin, S.; Su, S. M. Trends Mol. Med. 2010, 16, 387.

[4] Green, A.; Beer, P. N. Engl. J. Med. 2010, 362, 369.

[5] Kao, H. W.; Liang, D. C.; Wu, J. H.; Kuo, M. C.; Wang, P. N.; Yang, C. P.; Shih, Y. S.; Lin, T. H.; Huang, Y. H. Neoplasia 2014, $16,481$.

[6] Gross, S.; Cairns, R. A.; Minden, M. D.; Driggers, E. D.; Bittinger, M. A.; Jang, H. G.; Sasaki, M.; Jin, S. F.; Schenkein, D. P.; Su, S. M.; Dang, L.; Fantin, V. R.; Mak, T. W. J. Exp. Med. 2010, 207, 339.

[7] Zhang, Y.; Wei, H.; Tang, K.; Lin, D.; Zhang, C.; Mi, Y.; Wang, L.; Wang, C.; Wang, M. Genet. Test. Mol. Biomarkers 2012, 16, 991.

[8] Wang, X. L.; Liu, Y. H.; Jiang, J. H. Mod. Chin. Doct. 2020, 58, 15 (in Chinese). (王晓丽, 刘永华, 江锦红, 中国现代医生, 2020, 58, 15.)

[9] Lin, C.-C.; Hou, H. A.; Chou, W. C.; Kuo, Y.-Y.; Liu, C. Y.; Chen, C. Y.; Lai, Y. J.; Teng, M. H.; Huang, C. F. Am. J. Hematol. 2014 89, 137.

[10] Patnaik, M.-M.; Hanson, C. A.; Hodnefield, J. M.; Lasho, T. L.; Finke, C. M.; Knudson, R. A.; Ketterling, R. P.; Pardanani, A. Leukemia 2012, 26, 101.

[11] Ghiam, A. F.; Cairns, R. A.; Thoms, J.; Pra, A. D.; Ahmed, O.; Meng, A.; Mak, T. W. Oncogen 2011, 31, 3826.

[12] Li, Y.; Ma, L. Chin. J. Med. Imaging 2020, 28, 142 (in Chinese). (李锐, 马林, 中国医学影像学杂, 2020, 28, 142.)

[13] Kaneko, M. K.; Liu, X.; Oki, H.; Ogasawara, S.; Nakamura, T.; Saidoh, N.; Tsujimoto, Y.; Matsuyama, Y.; Uruno, A.; Sugawara, M.; Tsuchiya, T.; Yamakawa, M.; Yamamoto, M.; Takagi, M.; Kato, Y. Cancer Sci. 2014, 105, 744.

[14] Deng, H. M.; Duan, H. X. J. Clin. Hepatol. 2020, 36, 2856 (in Chinese).

(邓海敏，段华新，临床肝胆病杂志, 2020, 36, 2856.)

[15] Grassian, A. R.; Pagliarini, R. Curr. Opin. Gastroenterol. 2014, 30, 295.

[16] Yang, H.; Ye, D.; Guan, K.; Xiong, Y. Clin. Cancer Res. 2012, 18, 5562.

[17] Xu, W.; Yang, H.; Liu, Y.; Yang, Y.; Wang, P.; Kim, S. H.; Ito, S.; Yang, C.; Wang, P.; Xiao, M, T.; Liu, L. X.; Jiang, W. Q.; Liu, J.; Zhang, J. Y.; Wang, B.; Frye, S.; Zhang, Y.; Xu, Y, H.; Lei, Q. Y.; Guan, K. L.; Zhao, S. M.; Xiong, Y. Cancer Cell 2011, 19, 17.

[18] Janeta, P. M.; René, M.; Lemieux, E. A.; Jeffrey, O.; Saunders, F. G.; Salituro, J. T.; Giovanni, C.; Zhen, W. C.; Ding, Z.; Da, W. C.; Ping, C.; Kimberly, S.; Erica, T.; Fang, W.; Muriel, D.; David, V.; Penard, L.; Cyril, Q.; Veronique, S.; Stephane, D. B.; Stefan, G.; Lenny, D.; Hua, Y.; Luke, U.; Yue, C.; Hyeryun, K.; Sheng, F. J.; Zhi, W. G.; Gui, Y.; Zhi, Y. L.; Xiao, B. L.; Cheng, F.; Li, P. Y.; Andrew, O.; Lee, S.; Scott, B.; Shin, S. M.; Katharine, Y. ACS Med. Chem. Lett. 2018, 9, 300.

[19] Cho,Y. S.; Levell, J. R.; Liu, G.; Caferro, T.; Sutton, J.; Shafer, C. M.; Costales, A.; Manning, J. R.; Zhao, Q.; Sendzik, M.; Shultz, M.; Chenail, G.; Dooley, J.; Villalba, B.; Farsidjani, A.; Chen, J.; Kulathila, R.; Xie, X.; Dodd, S.; Gould, T.; Liang, G.; Heimbach, T.; Slocum, K.; Firestone, B.; Pu, M.; Pagliarini, R.; Growney, J. D. ACS Med. Chem. Lett. 2017, 8, 1116.

[20] Rehwinkel, H.; Panknin, O.; Ring, S.; Anlauf, S.; Siebeneicher, H.; Nguyen, D. WO 2015121210, 2015.

[21] Hu, Y.-Y.; Gao, A. H.; Liao, H.-H.; Zhang, M.-M.; Xu, G.Y.; Gao, 
L. X.; Xu, L.; Zhu, B. Y.; Gao, J. R.; Ye, Q.; Li, A. Arch. Pharm. 2018, e1800039.

[22] Liu, X.Q.; Hu, Y.-Y.; Gao, A.; Xu, M.; Gao, L.; Xu, L.; Zhou, Y.; Gao, J. R.; Ye, Q.; Li, J. Bioorg. Med. Chem. 2019, $27,589$.

[23] Wang, S. Y.; Guo, X. B. Chin. J. Org. Chem. 1989, 9, 124 (in Chinese) (王昭显，郭秀斌，有机化学, 1989, 9, 124.)

[24] Xiao, F.; Luo, Y.; Lü, W.; Tang, J. Chin. J. Org. Chem. 2010, 30, 311 (in Chinese). (肖锋, 罗宇, 吕伟, 汤杰, 有机化学, 2010, 30, 311.)

[25] Zhao, S. M.; Lin, Y.; Xu, W.; Jiang, W. Q.; Zha, Z. Y.; Wang, P.; Yu, W.; Li, Z. Q.; Gong, L.-L.; Peng, Y. J.; Ding, J. P.; Lei, Q. Y.; Guan, K. L.; Xiong, Y. Science 2009, 324, 261.

[26] Ward, P. S.; Patel, J.; Wise, D. R.; Abdel-Wahab, O.; Bennett, B. D.; Coller, H. A.; Cross, J. R.; Fantin, V. R.; Hedvat, C. V.; Perl, A. E.; Rabinowitz, J. D.; Carroll, M.; Su, S. M.; Sharp, K. A.; Levine, R.
L.; Thompson, C. B. Cancer Cell 2010, 17, 225.

[27] Noushmehr, H.; Weisenberger, D. J.; Diefes, K.; Phillips, H. S.; Pujara, K.; Berman, B. P.; Pan, F.; Pelloski, C. E.; Sulman, E. P.; Bhat, K. P.; Verhaak, R. G. W.; Hoadley, K. A.; Hayes, D. N.; Perou, C. M.; Schmidt, H. K.; Ding, L.; Wilson, R. K.; Berg, V. D.; Shen, H.; Bengtsson, H.; Neuvial, P.; Cope, L. M.; Buckley, J.; Herman, J. G.; Baylin, S. B.; Laird, P. W.; Aldape, K. Cancer Cell. 2010, 17, 510.

[28] Okoye-Okafor, U. C.; Bartholdy, B.; Cartier, J.; Gao, E. N.; Pietrak, B.; Rendina, A. R.; Rominger, C.; Quinn, C.; Smallwood, A.; Wiggall, K. J.; Reif, A. J.; Schmidt, S. J.; Qi, H, W.; Zhao, H. Z.; Joberty, G.; Faelth-Savitski, M.; Bantscheff, M.; Drewes, G.; Duraiswami, C.; Brady, P.; Groy, A.; Narayanagari, S. R.; Antony-Debre, I.; Mitchell, K.; Wang, H. R.; Kao, Y. R.; Christopeit, M.; Carvajal, L.; Barreyro, L.; Paietta, E.; Makishima, H.; Will, B.; Concha, N.; Adams, N. D.; Schwartz, B.; McCabe, M. T.; Maciejewski, J.; Verma, A.; Steidl, U. Nat. Chem. Biol. 2015, 11, 878.

(Cheng, F.) 